\title{
Sedimentary blue carbon dynamics based on chrono-sequential observation in a tropical restored mangrove forest
}

Raghab Ray ${ }^{1 *}$, Rempei Suwa ${ }^{2}$, Toshihiro Miyajima ${ }^{1}$, Jeffrey Munar ${ }^{3}$, Masaya Yoshikai ${ }^{4}$, Maria Lourdes San Diego-McGlone ${ }^{3}$, Kazuo Nadaoka ${ }^{4}$

${ }^{1}$ Atmosphere and Ocean Research Institute, The University of Tokyo, Kashiwa

raghab.ray@aori.u-tokyo.ac.jp; miyajima@aori.u-tokyo.ac.jp

${ }^{2}$ Japan International Research Center for Agricultural Sciences, Tsukuba

swrmp2005@yahoo.co.jp

${ }^{3}$ Marine Science Institute, University of the Philippines, Diliman

mlmcglone@msi.upd.edu.ph; jcmunar1@up.edu.ph

${ }^{4}$ School of Environment and Society, Tokyo Institute of Technology, Tokyo

yoshikai.m.aa@m.titech.ac.jp; nadaoka.k.aa@m.titech.ac.jp

Correspondence to: Raghab Ray (raghab.ray@aori.u-tokyo.ac.jp, raghab.ray@gmail.com)

\begin{abstract}
Among many ecosystem services, macro-climate regulation via the storage of large amounts of organic carbon (OC) in marine sediments (also known as 'blue carbon') has given mangroves enormous global attention due to their role in climate change mitigation. While there are many studies on blue carbon potential of intact mangroves (i.e. naturally growing), there have been very few on restored mangroves (i.e. planted). This study aims to address this knowledge gap by examining sediment development process during early colonization (rehabilitation) of mangroves in an OC-poor estuary in the Panay Island, Philippines. Based on endmember source apportionment in sedimentary organic matter, the contribution of mangrove plant material was higher at the older sites compared to the younger settings or bare sediment where there is more contribution of riverine input. A clear increasing gradient according to mangrove development was observed for bulk OC (0.06 to $3.4 \mu \mathrm{mol} \mathrm{g}{ }^{-1}$ ), porewater OC (292 to $2150 \mu \mathrm{mol} \mathrm{L}^{-1}$ ), sedimentary OC stock ( 3.13 to $77.4 \mathrm{Mg} \mathrm{C} \mathrm{ha}^{-1}$ ) and OC loading per surface area (7 to $223 \mu \mathrm{mol} \mathrm{m}^{-2}$ ). The estimate of carbon accumulation rates ( 6 to $33 \mathrm{~mol} \mathrm{~m}^{-2} \mathrm{yr}^{-1}$ ) based on chrono-sequence are within the global ranges and show an increasing pattern with mangrove age. Although a differential yet systematic pattern of increasing OC sink based on short-term chrono-sequence can define the role of a mangrove rehabilitation program, there is a need for long-term monitoring to verify the consistently elevated $\mathrm{OC}$ with mangrove growth.
\end{abstract}

\section{Introduction}

The term 'Blue Carbon' was first introduced more than a decade ago to describe the large quantity of organic carbon (OC) present in shallow coastal habitats like mangroves (Nellemann et al., 2009). Mangroves, located around the tropical and subtropical coastal regions are known for storing significant amounts of OC in the sediment and vegetation biomass. Out of typical total carbon stock of $739 \pm 28 \mathrm{Mg} \mathrm{C} \mathrm{ha}^{-1}$ in mangrove ecosystems, sediment OC accounts for 
respectively (Alongi, 2020). Mangrove sediment is the largest depository of OC owing to their efficiency in trapping suspended sediments and associated sedimentary organic matter (SOM), high algal OM (benthic algae and phytoplankton) and vascular plant-derived OM and low decomposition rates of SOM under anoxic conditions in the sediment $(0.5 \mathrm{~m}$ to $3 \mathrm{~m}$ depth core generally represent $\sim 49$ to $98 \%$ of ecosystem OC stock, Donato et al., 2011). The high $\mathrm{C}$ sink capacity of mangroves make them one of the key ecosystems that contribute to climate change mitigation by capturing large amount of atmospheric $\mathrm{CO}_{2}$ (Howard et al., 2017). However, there has been a rapid loss of mangroves due to land use and deforestation which has resulted the release of OC stored in the sediments back to the atmosphere as $\mathrm{CO}_{2}$ (Valiela et al., 2001). For instance, conversion of mangroves to aquaculture ponds, paddy fields, pastures, and tree removal have resulted in OC stocks per unit area becoming 2 to 8 times lower than the intact mangrove forests (Salmo et al., 2013; Kauffman et al., 2017; Sharma et al., 2020). Therefore, quantification of blue C provides added value for mangrove protection to ecosystem services and serves as a useful management tool when implementing plans for mangrove sustainability and productivity (Sheehan et al., 2019). During the last three decades, several countries have implemented mangrove rehabilitation and restoration programs effectively to reverse mangrove forest cover loss. Mangrove restoration efforts such as Reducing Emissions from Deforestation and forest Degradation (REDD+) have reduced $\mathrm{C}$ emissions by considering loss from the above ground biomass part only (Pendleton et al., 2012). Country like the Philippines have started to address REDD+, loss of mangroves, and degradation of blue $C$ habitats through their policies and rehabilitation management plans. To assess effectiveness of such efforts, there should be a comparison between the intact and restored mangrove forest in terms of sediment OC stock and accumulation rates. Restored mangrove forests are rarely explored globally with some notable exceptions in the subtropical coastal regions of China (Ren et al., 2010; Lunstrum and Chen, 2014; Wang et al., 2021), and Vietnam (Van Hiew et al., 2017; Dung et al., 2016). In this study, an evaluation based on chrono-sequential observation (a.k.a. "space-for-time-substitution" or SFT; Pickett, 1989) is made for sites in the Philippines where restoration is a viable option. The judicious use of chrono-sequential observation or SFT has already advanced our understanding of shortterm temporal dynamics of carbon in naturally expanding mangroves (e.g., 66-year by Walcker et al., 2017; 70 years by Kelleway et al., 2016). Chrono-sequence is an indirect approach or a type of 'natural experiment' (Pickett, 1989) that can be applied to the relatively younger sites (e.g., Bakhawan Ecopark, Philippines, examined in this study) where all environmental and biological conditions of the experimental sites must be identical except for the age, and species diversity is low (Nilsson and Wilson, 1991; Walker et al., 2010).

The capacity of nearshore vegetated habitats as blue carbon sink is controlled by geophysical constraints such as sediment supply rate, depositional conditions, and tidal elevation (Miyajima et al., 2017; Jiménez-Arias et al., 2020). Based on chrono-sequential studies of intact mangroves, OC accumulation in sediments increased with tree age, and OC sources change with mangrove development (Lovelock et al., 2010; Marchand et al., 2017; Walcker et al., 2018). Most of the OC stored in mangrove sediment change from plant-derived OM to algal OM at a proximal tidal flat (Gontharet et al., 2014; Prasad et al., 2017; Ray et al., 2018). With the development of mangroves, higher vascular plant or mangrove-derived OC sources may dominate OM pool (Marchand et al., 2006). A significant fraction of mangrove-derived OC that has accumulated on top of the bare sediment can be washed away to the nearshore waters by tidal action (Brown et al., 2021; Ray et al., 2020). By considering bare sediment and old growth mangrove stands 

blue $\mathrm{C}$ dynamics can be captured for restored mangroves. Stable isotope ratio of carbon $\left(\delta^{13} \mathrm{C}\right)$ is frequently used to evaluate the relative contributions of end member sources to the OM pool through mixing models with either $\delta^{15} \mathrm{~N}$ or C:N ratios (Ray and Shahraki 2016; Sasmito et al., 2020). The use of such biogeochemical controls on blue C dynamics has rarely been reported for the restored mangroves (Kandelia dominated, Van Hiew et al., 2017).

In this study, we hypothesize that the restored mangroves increase sediment $\mathrm{C}$ storage in accordance with maturity of vegetation. To test this, we (1) calculated total OC (TOC), dissolved OC (DOC), and OC accumulation rate along a chrono-sequence of restored mangroves forests located in the Philippines, and (2) examined how blue $\mathrm{C}$ varies with sedimentary geochemical properties (OC, bulk density, specific surface area). The isotopic signatures such as $\delta^{13} \mathrm{C}$ which allows for an efficient provenance analysis of SOM was examined. Additionally, particulate OC (POC) present in the surface water was examined to assign different end member sources in the SOM pool (e.g., plant organ, riverine and pelagic algae).

\section{Material and Methods}

\subsection{Study area}

Sampling was conducted in a planted mangrove forest, locally known as Bakhawan Ecopark, located in Kalibo city on Panay Island in Central Philippines during the wet season (September 2018 and 2019) and dry season (February 2019) (Fig. 1, $11^{\circ} 43^{\prime} 12^{\prime \prime} \mathrm{N}, 122^{\circ} 23^{\prime} 39.12^{\prime \prime} \mathrm{E}$ ). The Bakhawan Ecopark is the remnant area of a former deltaic mangrove at the mouth of the Aklan River (Duncan et al., 2016). Aklan River which has a drainage area of $852 \mathrm{~km}^{2}$ flows into the northwestern coastal area of Kalibo, continuously depositing high sediment yield to form the alluvial plain down the river. Sediments entrained by the longshore current formed sandbars, beach ridges, and coalesced mouthbar deposits. To prevent the damages by coastal flooding, a large portion of the sea facing mudflat were planted with 45 ha of Rhizophora apiculata and 5 ha of Nypa fruticans in 1990 by a cooperative comprised of local families (Kalibo Save the Mangrove Association or KASAMA). An additional 20 ha of Rhizophora spp. were planted in 1993 (Primavera, 2004) for the purpose of stabilizing the shoreline, decreasing sedimentation to the offshore, and increasing fish stocks and wood production (Department of Environment and Natural Resources or DENR, Philippines). Insect damage of the plantation in 1997 was followed by infilling of naturally-recruited Avicennia marina and Sonneratia alba. The seafront area was replanted in 2006 with Rhizophora apiculata, and subsequently recolonized naturally by A. marina and Sonneratia alba (Duncan et al., 2016). New recruitment of both A. marina and $R$. apiculata took place on the mud bank in May/June 2019. The inland part of the Ecopark is dominated by naturally growing mangroves. Natural growth of mangrove trees and planting efforts since the 90's at the Aklan River mouth stabilized and enlarged the mangrove forest by at least $627 \%$, to a flourishing 121 hectares today. Based on remotely-sensed data, the land area of the forest has increased by $52.42 \%$ on average every five years since 1985. The Food and Agriculture Organization of the United Nations has cited the Bakhawan mangrove for excellence in forest management (Cadaweng \& Aguirre 2005). 
Tide in the Bakhawan Ecopark is semidiurnal microtidal with the highest amplitude of around $2 \mathrm{~m}$. The mangrove forest floor is fully inundated during the high tide. At the mouth of the Aklan River, water meanders along a small channel between the sandbar and mangrove-lined coast. The climate of Aklan is categorized as Type III (according to the Philippines Atmospheric, Geo-Physical, and Astronomical Services Administration) with no pronounced maximum rain period except for short dry periods of 1-3 months (December to February or March to May). The rest of the year represents wet season with total annual rainfall of $3200 \pm 775 \mathrm{~mm}$ and mean temperature of $27.2{ }^{\circ} \mathrm{C}(2017$ 2018, JRA-55 reanalysis).

Sediment sampling locations were categorized according to mangrove ageing as bare sediment (BS, 0-yr), pioneer mangroves (PM, 0.25-yr), young mangrove (YM, 10-yr), adult mangrove (AM, 20-yr) and mature mangroves (MM, 30-yr). These categories are partly influenced from Marchand et al. (2003) who examined chrono-sequential sedimentary $\mathrm{OC}$ in the naturally growing Avicennia dominated mangroves in the French Guiana muddy coast. The center of the mangrove forest is dominated by AM and the sea facing edge of the Ecopark has decreasing mangrove age from MM to PM. Both BS and PM are inundated during the high tide. Rhizophora apiculata is the dominant species at YM, AM and MM, while mixed mangroves (Avicennia and Rhizophora sp.) are found at PM. Among two sites of bare sediment, BS1 which is closer to YM, was sampled during the wet season, while BS2 which is isolated from the mangrove sites, was sampled in the dry season, (Fig. 1).

\subsection{Sampling procedure}

Sediment thickness was measured at each site using a tool for cone penetration test (KS-159, Kansaikiki Inc.) (Yoshikai et al., 2021). Single core was collected at each site during the low tide by manually pushing a Eijkelkamp peat sampler (DIK-105A, Ø $52 \mathrm{~mm}$, length $50 \mathrm{~cm}$ ) into the sediment. A total of 8 cores were retrieved during the survey period with seasonal collection made at AM, YM and MM sites. The GPS coordinates at all sampling sites were recorded to locate them again for duplicate sampling in a different season (Garmin MAP64s). Immediately after sampling, each core was sectioned into $2 \mathrm{~cm}$ interval up to the first $10 \mathrm{~cm}$ and $5 \mathrm{~cm}$ interval beyond $10 \mathrm{~cm}$ depth. Average sample depth at each site was consistently around $50 \mathrm{~cm}$. In situ $\mathrm{pH}$ (NBS scale), temperature and oxidation reduction potential (ORP, $\mathrm{AgCl}$ electrode) were recorded for each section using hand-held multiparameter probes (HORIBA pH-conductivity sensors, WTW redox sensor). About 0.8 to $1 \mathrm{~kg}$ cores were collected from each site. Visible root material, decaying plant matter and dead wood were removed from the sediment sample in the field. Samples were kept in styrofoam box and brought to the laboratory within 3-4 hours after collection.

Additional sediment cores for porewater sampling were collected inserting PVC corer manually at each site $(6.5 \mathrm{~cm}$ inner diameter, $70 \mathrm{~cm}$ length). A total of 7 cores were retrieved on seasonal basis (single core from each site per season). Immediately after retrieval, the top and bottom ends of the corer were closed using rubber caps. Rhizon tubes (Rhizosphere Research Products) were inserted to the holes drilled at specified intervals $(0.5 \mathrm{~cm}$ interval till the first $4 \mathrm{~cm}$ followed by $2 \mathrm{~cm}$ interval up to the $10 \mathrm{~cm}$, and finally $5 \mathrm{~cm}$ interval). A Rhizon tube is a small microporous polymer tube ( $2.5 \mathrm{~mm}$ diameter, $<0.2 \mu \mathrm{m}$ pore size of the membrane) connected to a plastic syringe ( $25 \mathrm{ml}$ capacity) by a standard luer-lock connector. Around $8-10 \mathrm{ml}$ of porewater were extracted in $\sim 1$ hour. Salinity of the extracted 
Tidal water sampling was conducted along the salinity gradient ( 0 to 33 ) in the Aklan River. For this study, three representative sites were chosen, the upstream of the Aklan River and outer-shore as potential endmember sources of SOM, and the river channel very close to BS site during the high tide. More details of water sampling techniques can be found in the supplementary material. A global tide prediction model (NAO.99b, Matsumoto et al., 2000) was used to correct water depth data to relative elevation at each site from Mean Sea Level or MSL.

In the laboratory, pre-weighed wet sediment subsamples were oven dried at $60^{\circ} \mathrm{C}$ for 48 hours to allow for calculation of dry bulk density (BD) and water content. For sediment subsampling, open mouth plastic syringe was used $(2 \mathrm{~cm}$ id and $1.5 \mathrm{~cm}$ length). Bulk density $\left(\mathrm{g} \mathrm{cm}^{-3}\right)$ was determined as the dry sediment weight $(\mathrm{g})$ divided by the initial volume $\left(\mathrm{cm}^{3}\right)$. Rest of the wet sediment samples were freeze dried using a Benchtop Freeze Dry System (Labconco). The freeze-dried samples were gently crushed using a mortar and pestle and passed through a $1 \mathrm{~mm}$ mesh stainless steel sieve to remove the large gravel (refer as coarse fraction). The sieved samples were stored in tightly capped glass vials under $<40 \%$ relative humidity.

\subsection{Chemical analyses}

The dried and homogenized sediment samples were subjected to acid treatment to remove inorganic carbon. Approximately $1 \mathrm{~g}$ of dried sample was placed into screw-capped glass tubes $(10 \mathrm{~mL})$, and $2.0 \mathrm{~N}$ hydrochloric acid $(\mathrm{HCl})$ solution was added to the sediment dropwise until all the carbonate was converted to $\mathrm{CO}_{2}$. After centrifugation for $15 \mathrm{~min}$ at $2000 \mathrm{rpm}$, followed by washing with deionized water and decantation, the final residue in the tube was dried at $60{ }^{\circ} \mathrm{C}$ overnight. Once cooled, the dried samples were weighed into a tin capsule $(10 \times 10 \mathrm{~mm})$, folded and kept temporarily in a 48-well microtiter plate until analysis.

The concentrations and isotope ratios of $\mathrm{OC}$ and total nitrogen (TN) in the treated samples were determined simultaneously by EA-IRMS (FLASH 2000/Conflo IV/DELTA V Advantage, ThermoFisher Scientific, Bremen, Germany). Two standard materials of different $\delta^{13} \mathrm{C}(-26.4$ to $-19.6 \%)$ and $\delta^{15} \mathrm{~N}(2.5$ to $5 \%$ )) values (SI Science Ltd., Saitama, Japan) were used for calibration. The measured isotope ratios were represented using conventional $\delta$-notation $\left(\delta^{13} \mathrm{C}\right.$ and $\delta^{15} \mathrm{~N}$, in \%o) with Vienna Pee-Dee Belemnite and atmospheric $\mathrm{N}_{2}$ as the reference materials. The instrumental analytical precision was normally within $\pm 1 \%$ for the $\mathrm{OC}$ and TN concentrations and $\pm 0.1 \%$ for $\delta^{13} \mathrm{C}$ and $\delta^{15} \mathrm{~N}$.

Measurement of specific surface area (SSA) in sediment was performed by the multipoint Brunauer-Emmett-Teller

(BET) method based on $\mathrm{N}_{2}$ gas adsorption under reduced pressure (details refers to Miyajima et al., 2017). The dried and homogenized sediment samples were heated at $350{ }^{\circ} \mathrm{C}$ for $12 \mathrm{~h}$ followed by calculation of weight loss on heating after 1 hour. Between $0.5 \mathrm{~g}$ and $2.0 \mathrm{~g}$ of the treated samples were weighed into glass flasks and desiccated in vacuo at $350{ }^{\circ} \mathrm{C}$ for $3 \mathrm{~h}$. Immediately after cooling, a multipoint BET measurement was performed with $\mathrm{N}_{2}$ (purity $>99.99 \%$ ) as the adsorbate using the BELSORP mini II (MicrotracBEL, Osaka, Japan) surface area analyzer. The slope of the BET plot in the linear region was used for estimating the SSA. 


\subsection{Data analyses}

The results of the OC and TN concentrations, and the SSA were expressed as $\mu \mathrm{mol}$ and $\mathrm{m}^{2}$ per unit dry weight of bulk

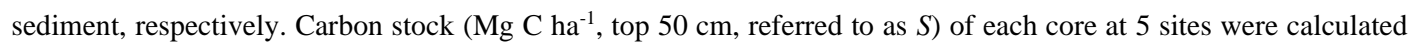
on seasonal basis as

$S=\sum_{i=0}^{n} C \mathrm{n} \times \rho n \times l$.

Where $C \mathrm{n}$ is $\mathrm{C}$ concentration (mass \%) and $\rho n$ is the bulk density $\left(\mathrm{g} \mathrm{cm}^{-3}\right)$ of the sample, and $l(\mathrm{~cm})$ is length of sample section. The amount of OC preserved per unit surface area of sediment particles is referred to as OC loading (OC/SSA in $\mu \mathrm{mol} \mathrm{m}{ }^{-2}$, Mayer 1994).

In a chrono sequence study, it is common to apply linear regression model between mangrove age and $\mathrm{C}$ stock and derive slope, i.e., carbon accumulation rate (CAR) (Alongi, 2004; Walcker et al., 2018) or individually following the formula such as $\mathrm{CAR}=[(\mathrm{C}$ stock of the stand $)-(\mathrm{C}$ stock of the previous stand $)] /[($ age of the stand $)-($ age of the previous stand)] (Marchand et al., 2017). However, our results showed best-fit with exponential function for the relationship.

OC $\operatorname{stock}(\mathrm{mol} / \mathrm{m} 2)=a \cdot e^{b \cdot y r}$.

where $a$ and $b$ are constants determined from the field data as 100.34 and 0.058 , respectively, and $y r$ is the age of mangrove stands (years). Here we assume that with exponential increase of plant above ground mass with early mangrove growth, below ground root mass also increases that contribute significantly to OC accumulation with early mangrove development. However, because exact maturity stage of these mangroves is unknown, typical logistic curve equation that is otherwise used for the matured forest, was not applied, instead best-fitted exponential trend was used. Based on exponential model, slope was derived for the individual sample following the equation:

Slope or CAR $\left(\frac{m o l}{m 2 . y r}\right)=\left(\frac{d O C}{d t}\right)=a \cdot b \cdot e^{b . y r}$

Accordingly, CAR for the age class of mangroves $(0.25,5,10,15,20,25$ and 30 year) was calculated and fitted in the exponential curve and compared with the slope derived from the linear regression model.

To evaluate the effects of sampling Depth, Season and stand Types (i.e., chronology based) on $\delta^{13} \mathrm{C}, \delta^{15} \mathrm{~N}$ and C:N ratio of SOM, the general additive linear mixed model (GAM) was constructed with a gam function in a $\mathrm{R}$ package (mgcv). Depth, Season, Types and an interaction between Season and Types were treated as fixed effects where Depth was incorporated into the model. Using the results of gam, ANOVA was used to evaluate the significance of each variable with a significance level at $p=0.05$.

For subsequent provenance analysis, a binary source mixing model was applied (Parnell and Inger, 2016) based on mean values of $\delta^{13} \mathrm{C}, \delta^{15} \mathrm{~N}$ and $\mathrm{C}: \mathrm{N}$ ratio of sediment samples from different depth in each core. The samples obtained in different seasons were treated as independent samples. In total, seven mean values were used for the analysis of Bayesian mix model using multiple R packages (RGtk2, MixSIAR, splanc). The endmember sources of OM chosen 
for this study were green leaf of Rhizophora apiculata, POM (particulate organic matter) of marine and river water, and microphytobenthos (MPB). Among these endmembers except for POM, the $\delta^{13} \mathrm{C}, \delta^{15} \mathrm{~N}$ and OC:TN ratio for green leaf and MPB were obtained from the literature (refers to Table S1). Although OC:TN were shown to be largely variable between green $(\sim 30)$ and yellow/senescent leaves on sediment floor ( $\sim 50)$ of the Rhizophora apiculata, their $\delta^{13} \mathrm{C}$ values were the same (-28.5\%) (Nordhaus et al., 2017). For similar reason mangrove root is also not considered, instead leaf singularly presents as mangrove-derived OC source. Hence it is reasonable for this study to choose green leaves and avoid redundant increase of endmembers for the model. Microphytobenthos located on tidal flat between the interface of sea and land can also be variable depending on $\delta^{13} \mathrm{C}$ of dissolved inorganic carbon (photosynthesis substrate for MPB). This is similar to the riverine settings in French Guiana ('mixed MPB' $-20.9 \%$, Ray et al., 2018), and contrast to oceanic setting in Red Sea ('pure MPB' $-17.9 \%$, Shahraki et al., 2014). Number of endmembers were chosen carefully keeping small standard deviation of $\delta^{13} \mathrm{C}$ and OC:TN within each endmember and clearly separated with significant differences from each other (ANOVA, $\mathrm{p}<0.05$ ). We refrained from considering a large number of endmembers, and omitted less important endmembers or treated collectively some endmembers whose isotopic and elemental compositions are similar (e.g. plant parts such as leaf, root, litter). Since there was no seagrass recorded at or around the sites, its potential endmember contribution to the mangrove SOM was ignored. On the contrary, although the isotopic composition of MPB and marine POM were not very different, we selected MPB as endmember due to its visible presence on the exposed tidal flat (BS2) during the low tide.

\section{Results}

Maximum elevation of $0.45 \mathrm{~m}$ from the MSL was measured at the mature mangrove (MM) site, and minimum of $1.3 \mathrm{~m}$ was recorded for the bare sediment (BS) (Fig. 2). Mean porewater salinity, sediment temperature and $\mathrm{pH}$ did not vary significantly between the various stages of mangrove development (Fig. 2). Sediment thickness was higher in mangrove sediment $(140-265 \mathrm{~cm})$ than the tidal flat $(<100 \mathrm{~cm})$. Sediment bulk density at the top $50 \mathrm{~cm}$ increased with decreasing mangrove age tending to be maximum at BS ( 0.6 to $1.3 \mathrm{~g} / \mathrm{cm}^{3}, \mathrm{n}=93$, Table 1$)$. Specific surface area of the sediments varied from 9.8 to $21.2 \mathrm{~g} / \mathrm{m}^{2}(\mathrm{n}=19)$ with lowest value for the coarser bare sediment. Fraction of large gravels (>1 mm mesh size) tend to be higher going seaward. A consistent increment in sediment OC concentration (top $50 \mathrm{~cm}, \mathrm{n}=93$ ), TOC:TN molar ratio $(\mathrm{n}=92)$, and porewater DOC $(\mathrm{n}=64)$ was observed with the mangrove evolution (BS: $0.06 \mu \mathrm{mol} / \mathrm{g}, 21.9 \mathrm{~mol} / \mathrm{mol}$, and $292 \mu \mathrm{mol} \mathrm{L}^{-1}$; at MM: $3.4 \mu \mathrm{mol} \mathrm{g}^{-1}, 19.7 \mathrm{~mol} / \mathrm{mol}$, and 2150 $\mu \mathrm{mol} \mathrm{L} \mathrm{L}^{-1}$, respectively). The mean value of bulk $\delta^{13} \mathrm{C}$ became more negative with mangrove age $\left(\delta^{13} \mathrm{C}=-25.07 \%\right.$ at BS and $-28.9 \%$ at $\mathrm{MM}, \mathrm{n}=93$ ). The mean $\delta^{15} \mathrm{~N}$ varied from -1.15 at the BS to $1.06 \%$ at the adult mangrove (AM) site $(\mathrm{n}=90)$. Organic carbon $(\mathrm{OC})$ stock was determined to be maximum at the mature stand $(77.4 \mathrm{Mg} \mathrm{C} / \mathrm{ha})$ and lowest at the bare sediment (3.13 Mg C/ha). Similar to the trend of OC stock, OC loading varied widely between 4 and $380 \mu \mathrm{mol} / \mathrm{m}^{2}(\mathrm{n}=19)$, with mangrove sites having higher OC loading (mean: $\left.152 \mu \mathrm{mol} / \mathrm{m}^{2}\right)$ than the bare sediment $\left(25 \mu \mathrm{mol} / \mathrm{m}^{2}\right)$.

Vertical profile of sediment OC and $\delta^{13} \mathrm{C}$, specific surface area (SSA) and OC loading, and porewater DOC on seasonal basis are shown in Figs. 3-5. Sediment surface values $(0-10 \mathrm{~cm})$ of porewater salinity, $\mathrm{pH}$ and ORP changed significantly with mangrove ages in the wet season, $(\mathrm{p}<0.05$, Fig. S1), except for porewater salinity at bare sediment 


\subsection{Sediment condition and organic matter}

The results of dry bulk densities and granulometry (coarse fraction, SSA,) of the tidal flat and mangroves in Bakhawan Ecopark indicate that soils are relatively homogeneous with fine-grained fractions relatively prevalent towards the upper older mangrove region (mainly towards AM), while towards the shore, coarse-grained sands are more common on the tidal flat and younger mangroves (BS and YM, PM) (Fig. 2). Bulk densities (BD) at the sampling sites (0.3 to $\left.1.3 \mathrm{~g} \mathrm{~cm}^{-3}\right)$ were higher than the reported BD values across mangrove soils of the Indo-Pacific regions $(0.20$ to $0.92 \mathrm{~g}$ $\mathrm{cm}^{-3}$, Donato et al., 2011), with sand fractions dominating the lower intertidal zone. Specific surface area is primarily constrained by grain size and its vertical profile is presumably related to finer upward trend of sediment grain (Fig. $4 \mathrm{a}, \mathrm{c})$. The latter might have been a result of sediment-stabilizing function of mangroves or influenced by some landuse change in recent years (e.g., land use change can increase clay content via deposition of pollen, Shen et al., 2020) Furthermore, carbonate bearing minerals can influence SSA more on the tidal flat than the organic rich mangrove sediment. Among the older stands (MM and AM), higher SSA and sediment thickness, and low BD at the adult stands suggest dominance of finer grained clay material because of the long-term presence of mangrove itself, and the narrow sandbar halfway down the Ecopark (Fig. 1) that may close off the older mangroves from higher wave energy and shift deposits of finer grains. Total organic carbon is higher at the older sites than the younger ones due to such fine-grained (silt + clay) sediments that tend to have higher TOC than the coarse sands (Canfield, 1994). Fine-grained silt has larger SSA that create higher capacity to adsorb OM (Mayer, 1994).

Among the physicochemical properties, lower porewater salinity at the BS than the mangrove sites indicate greater dilution from direct input of river water, which become less with increasing elevation level inside the forest floor (Fig. 2). On temporal scale, overall low porewater salinity during the wet season is more likely linked to rainwater dilution (350-450 mm in September, 75-150 mm in February, JRA-55 Reanalysis) and elevated groundwater level. Because of shading effect, surface sediment temperature at the mangrove vegetated sites was lower than the sun-exposed BS or PM. Lowest recorded ORP at BS strongly suggests that exchange of porewater with overlying water is limited, and this may have implication on the interpretation of porewater chemistry (i.e., DOC, section 4.3).

It has been observed that mangrove sediments in the river-dominated estuary accumulate larger proportion of the mangrove-derived OM than those in the tide-dominated estuaries/oceanic mangroves dominated by marine algae (e.g., Indonesian mangroves, Kusumaningtyas et al., 2019; Latin American, Gontharet et al., 2014; Middle-East, Ray and Shahraki, 2016). In the microtidal riverine setting of the Bakhawan Ecopark, OM input from land sources is more dominant than the marine sources at the mangrove sites (Fig. 6). End-member mixing model suggests that there is a clear gradient with respect to the relative proportion of OM sources along the tidal flat-mangrove continuum (Fig. 7). Sediments from cores at bare sediment and pioneering mangrove sites show the predominance of OM probably derived from fluvial transport of eroded organic material within the catchment. Upon transport into the coastal area, fine sediment and POM accumulate in calm shallow water channel at the topographically lowest elevation zone, (Fig. 2) and consequently the longer inundation period facilitates sedimentation and deposition of the suspended matter. Similar values of $\delta^{13} \mathrm{C}$ in surface water POC upstream (-25.9\%, Table S3) and sediment OC at the bare sediment and pioneering mangroves (mean -26\%) support their upstream allochthonous sources. A sizeable contribution from MPB 
may not be ruled out at bare sediment despite its minimal contribution from the mixing model (Fig. 7). In a companion study, other than the visible evidence of green algal patches, we measured day-time $\mathrm{CO}_{2}$ uptake flux on the tidal flat, which contrasts with emission flux at the forested sites (tidal flat: -4 to $-2 \mathrm{mmol} \mathrm{m}^{-2} \mathrm{hr}^{-1}$, mangrove: $5-12 \mathrm{mmol} \mathrm{m}^{-2}$ $\mathrm{hr}^{-1}$, Ray et al., unpublished). Strikingly low OC:TN ratio at the surface sediment and minimum $\delta^{15} \mathrm{~N}$ suggests presence of $\mathrm{N}_{2}$ fixing bacteria on the tidal flat during exposed tide condition. The slightly higher mangrove contribution to SOM in pioneering mangroves (up to $~ 54 \%$ ) clearly indicates additional OM input from the small growing plants along the channel.

At the topographically higher mangrove sites, greater contributions of autochthonous sources (i.e., mangrove plant materials) are correlated with lower $\delta^{13} \mathrm{C}$ and higher $\mathrm{OC} / \mathrm{TN}(>12)$. This is favored by relatively high bed elevation and decrease in submersion time promoting retention of detrital OM in the sediment layer (shown as leaf OM, Fig. 7). Although such evidence of greater plant input to SOM at interior mangrove sites compared to mudflats are not new for the intact forests (Marchand et al., 2003; Sanders et al., 2010; Matos et al., 2020), it is rare for restored mangroves considering an extended gradient from mudflat to mangrove appearance (except in Vietnam, Van Hiew et al., 2017).

Terrestrial C3 vascular plants, like mangrove plant organ have C/N ratios of around 12 or higher (Prahl et al., 1980) as it is composed predominantly of lignin and cellulose, which are nitrogen poor. The significant positive correlation between TOC and TN ( $r^{2}=0.96$ at BS, PM, YM, and AM; $\mathrm{r}^{2}=0.42$ at MM, figure not shown) in the sediments indicate that the $\mathrm{C}$ and $\mathrm{N}$ in the samples are predominantly associated with the organic pool. This suggests the protective role of early mangrove recruitment on sedimentary organic matter as seen in European coastal wetland (Jiménez-Arias et al., 2020). It is noteworthy that such correlation is relatively poor at the mature stands. Although the exact reason for this is unknown, the abundance of benthic animals during another complimentary experiment (burrow density at MM: $150 \pm 55$, YM: 70 \pm 62 , BS: $5 \pm 2$ individual $/ \mathrm{m}^{2}$, Ray et al., unpublished) might suggest intense bioturbation and sediment remobilization.

\subsection{Vertical profile of organic carbon}

The difference in the sediment physicochemical and OC profile at the upper $50 \mathrm{~cm}$ of the layers may result from multiple factors that promote OM decomposition, such as immediate exposure of litter in surface layers (e.g., managed Rhizophora in Malaysia, Ashton et al., 1999), while coarse and fine roots contribute to carbon and nutrients at shallower depth (reported down to $52 \mathrm{~cm}$ for 27-yrs planted Rhizophora in Vietnam, Arnaud et al., 2021). Multiple mid-layer peaks of TOC are sometimes observed which presumably reflects the influence of root biomass (Fig. 3). This study showed that root activity within the sediment column is essentially dominant when comparing vegetated sites with bare sediment. Assuming a mixture of algae (marine POM plus MPB, $\delta^{13} \mathrm{C}=-21.07 \%$ ), and mangrove root/plant organ $\left(\delta^{13} \mathrm{C}=-28 \%\right.$ ) as two major end-member sources of the sediment OM pool, provenance analysis confirms that roots contribute maximum at the old stands (75-100\%) and minimum at BS and PM (52-72\%) corroborating to the TOC peaks observed at different depths (particularly between 10-25cm, Fig. 3a,b).

Organic carbon profile was almost uniform in both seasons suggesting a dominant OM source prevailed down the cores. Root exudates like sugars, amino acids are suggested to be the main carbon source for the localized microbes 
350 (Bouillon and Boschker 2006; Jiang et al., 2017). The role of burrowing crabs as carbon sink has also been reported at deeper soil layers of Avicennia stands in Kenya (40-80 cm, Andreetta et al., 2013) where burrowing sesarmids provide a continuous supply of fresh organic matter down the profile. At low tide, presence of water with low oxygen saturation, covering the bottom of the burrows avoids oxidation by creating an extension of sediment-air interface favoring greater OC accumulation (Kristensen, 2004; Smith III et al., 1991). The same study in Kenya reported greatest OC concentration where crab population were maximum., otherwise hypo- or anoxic, and create an extension of costal marshes sediment-air interface favoring greater OC accumulation. In this study, bioturbation might play an important role in carbon accumulation at the sediment horizon of the older stands where higher benthic communities were found compared to the tidal flat and younger mangrove sites.

The depth-wise relationships between sediment OC and porewater DOC are less obvious (Fig. 3, 5). Porewater DOC varies disproportionally with OC. The distinct feature of vertical DOC profile is the non-uniform distribution of concentration with mangrove age in contrast with the relatively uniform profile at bare sediment. Porewater DOC in non-vegetated sediment is known to be primarily controlled by oxygen availability and the presence of microphytobenthos that could drive porewater dynamics via OC leaching compared to mangrove sediments. At the vegetated sites, fluorescence and hydrophobic DOC of high molecular weight is known to drastically increase in anoxic coastal porewaters (Komada et al., 2004; Marchand et al., 2006). At the vegetated sites, porewater DOC concentrations shows higher concentrations with depth that is most likely a reflection of the net effect of diagenesis, subsurface transport and partial control via root uptake and release. Though salinity profile is not exactly like DOC, yet the salinity peaks at the sub surface depth, thereby a uniform pattern followed at AM and MM. This may lead us to hypothesize that water absorption by roots at the upper sediment may be augmented by the presence of radial mangrove roots leading to an increase of salinity at some sites and gravitational percolation of salt water and DOC to greater depths. However, unlike porewater salinity that is lower in wet season than dry season due to rainwater dilution, DOC did not vary seasonally at adult mangrove and mature mangrove sites suggesting perennial source and retention in the sediment. The porewater profile of salinity and DOC in mangrove sediments is very rare in the literature. One such comprehensive dataset by Marchand et al. (2006) in French Guiana reported similar findings of higher DOC at greater depth with mangrove ageing but no direct correlation with other co-variables. Like shown many years ago by Marchand et al. (2006), the influence of seasonal mangrove productivity and root activity on DOC vertical profile may be evident also for this study, however, detailed research is necessary to understand such relationship.

\subsection{Increase of organic carbon with mangrove development}

The average TOC concentration in the top $50 \mathrm{~cm}$ mangrove sediment (PM to MM) in Bakhawan Ecopark is lower

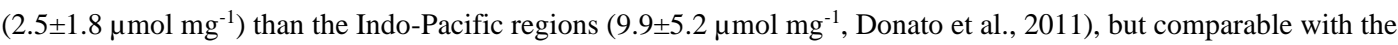
global mean $\left(1.7 \mu \mathrm{mol} \mathrm{mg}{ }^{-1}\right.$, Kristensen et al., 2008) and other restored mangroves in SE Asia (e.g., $2.2 \pm 0.05 \mu \mathrm{mol}$ $\mathrm{mg}^{-1}$ in Vietnam, Dung et al., 2016) and China (4.2 $\pm 0.3 \mu \mathrm{mol} \mathrm{mg}{ }^{-1}$, Nam et al., 2016). Absence of peat organic layer at the sampled sites and fast decomposition observed in separate $\mathrm{CO}_{2}$ emission measurement (benthic emission: 8 $\mathrm{mmol} \mathrm{m} \mathrm{hr}^{-1}$ at upper limit of global range 0.25 to $10.4 \mathrm{mmol} \mathrm{m}^{-2} \mathrm{hr}^{-1}$, Bouillon et al., 2008, Ray et al., unpublished) are the possible reasons behind such low to moderate OC in sediment. Besides that, rapid flushing out of POC favored 

$0-25$, Table S4) coming from the upstream and mangrove sites that flushed away via the channel to offshore $(-25.0$ $\%$ at salinity 33 ) at ebb time.

The present result shows that the development of restored mangrove forests could improve sediment OC as indicated by a clear progression in sediment TOC among the planted mangroves of different developmental stages leading towards soil maturity. The accumulation of $\mathrm{OC}$ in the mangrove sediment may be attributed to the increases in belowground root expansion with stand age (Salmo et al., 2014). Because of restricted water exchange with the seawater, mature Rhizophora stands accumulate higher mangrove derived OM (leaf litter and decomposing fine roots) than the young and pioneering stand, therefore shows higher TOC. For the adult mangrove stands (AM) despite their moderate biomass, oxic conditions (positive ORP) may have favored OM decomposition in the wet season resulting into lower TOC than at MM. Such non-linear correlation of OC with mangrove chrono-sequence is in line with other works in the restored (Lunstrum and Chen, 2014; Van Hiew et al., 2017) and intact forests (Lovelock et al., 2010, Marchand et al., 2017).

Like TOC concentration, OC stock in sediment gradually increased with chrono-sequence which is consistent with other recent studies on mangrove plantations (Lunstrum and Chen, 2014; Van Hiew et al., 2017; Wang et al., 2021). Salmo et al., (2013) previously reported higher above ground biomass (AGB) in 17-yr old Rhizophora than the 12-yr old stands (101.8 versus $51.4 \mathrm{Mg} \mathrm{ha}^{-1}$ ) at the Bakhawan Ecopark. Fine root production has also been found to increase with AGB and contribute to sediment OC stock more in mature mangroves (Zhang et al., 2021). On a global basis, OC stock is mostly reported for sediment cores of $1 \mathrm{~m}$ depth. If core depth is normalized to $50 \mathrm{~cm}$, our results still give comparable estimates ( 3 to $77 \mathrm{Mg} \mathrm{C} \mathrm{ha}^{-1}$ ) to the limited assessments of restored mangrove park, such as in north central Vietnam (54 to $84 \mathrm{Mg} \mathrm{C} \mathrm{ha}^{-1}, 0$ to 27-yrs of Kandelia obovats; Van Hieu et al., 2017), Pichavaram (41 to 94 $\mathrm{Mg} \mathrm{C}^{-1}, 12$ to 21-yrs of Rhizophora spp. (Gnanamoorthy et al., 2019) and Bhitarkanika Conservation in India, (38 Mg C ha-1, 5-yrs Kandelia candel, Bhomia et al., 2016). However, our stock estimate is lower than the organic soil of 410 oceanic setting in Sulawesi, Indonesia (c.a. 150-300 Mg C ha-1, more than 10 years of R. apiculata, Cameron et al., 2019). Sediment OC stock is largely dependent on vegetation biomass and extent of litter input. Salmo et al., (2014) reported that 17- and 18-year old Rhizophora stands at the Bakhawan Ecopark had 30-40 \% lower AGB compared with the natural mangroves (150 ton $\mathrm{ha}^{-1}$ ) while 50-year old stands had similar AGB (132 ton ha ${ }^{-1}$ ) with natural mangroves. Another reason might be the river dominated mangrove settings which are known to transport high

415 allochthonous input and deposit mineral sediment that dilutes OM and lowers OC stocks than the marine settings where mangrove-derived OM increase carbon stock in the sediment (Jennerjahn, 2020). Another reason could be sediment reworking during restoration or plantation work that can mobilize $\mathrm{OC}$ at least from the top $10 \mathrm{~cm}$ of the sediment. The rapid turnover may lead to reduction in OC stock. From a more general perspective, sediment OC stock depends on the distribution of fine roots (Noguchi et al., 2020), and efficient redox-dependent decay processes like sulfate reduction that promote OM preservation and increase OC stock in older stands isolated from the sea (Lambs et al., 2008). 
Increase in porewater DOC concentrations observed from tidal flat to pioneer mangrove then to older mangrove seems to reflect the increasing pattern of bulk OC (Fig. 2). With greater biomass, (mean tree height: PM <1m, YM 3-4m, AM 6-8m, MM 10-15m, data not shown), sediment TOC and porewater DOC concentration successively increased. A similar trend for bulk and dissolved OC was observed in the naturally growing Avicennia dominated mangroves in the Amazonian coastline (Marchand et al., 2006). With progression of chrono-sequence, we may infer that the higher the biomass, the higher the TOC, and the higher the DOC concentrations in the shallow sediments.

Organic carbon preservation in marine sediments can be influenced by the physical factors such as association of OC with the surface of sediment mineral particles, also known as OC loading (Kiel and Mayer, 2014). Sediment with high SSA tend to be rich in clay, iron and aluminum and store greater amounts of OM than low-SSA soils due to intimate organo-mineral association (Mayer,1994). Therefore, OC loading can be considered as a proxy for blue carbon preservation and supply in marine system, although there has been no account of such result for mangroves worldwide.

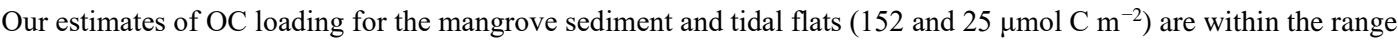
of continental margin sediment (40-80 $\mu \mathrm{mol} \mathrm{C} \mathrm{m}{ }^{-2}$, Mayer, 1994), vegetated marine sediment (56-67 $\mu \mathrm{mol} \mathrm{C} \mathrm{m}^{-2}$, Miyajima and Hamaguchi, 2017), and floodplains (16-42 $\mu \mathrm{mol} \mathrm{C} \mathrm{m}^{-2}$, Goni et al., 2014), but much lower than in the

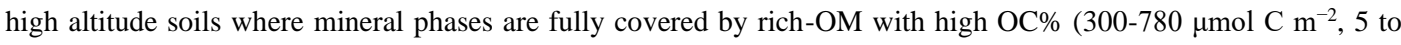
10\%; Wagai et al., 2009). At the Bakhawan Ecopark, variability of OC loading between mangrove sediment and tidal flat can be explained by the difference in spatial extent of individual sampled site. For example, when SSA was greater than $15 \mathrm{~m}^{2} \mathrm{~g}^{-1}$ (at AM and MM), significant negative correlation was observed between OC and SSA $\left(\mathrm{r}^{2}=0.95\right.$, $<0.01, \mathrm{n}=7$, figure not shown) indicating that net accumulation rate of OC in these sites are not dependent on mineral particles but on mangrove-derived supply of OM. Whereas at BS with mean SSA $<15 \mathrm{~m}^{2} \mathrm{~g}^{-1}$, a quasi-significant positive relationship between these two variables suggests the possible role of physical sorption of OC in the riverine sediment mineral matrices for stabilization and sequestration of organic carbon $\left(r^{2}=0.50, n=6\right)$. Therefore, sediment in the mangroves does not share a common OC sequestration mechanism as with the pelagic continental shelf and seagrass sediments.

\subsection{Accumulation of organic carbon}

\subsubsection{Relevance of chrono-sequence approach}

Several studies have relied on direct measurement of carbon accumulation rates (CAR) by combining sedimentary C content and soil accumulation rates estimated from radioisotopes, ${ }^{210} \mathrm{~Pb}$ and ${ }^{137} \mathrm{Cs}$ or natural markers like volcanic ashes (Sanders et al., 2010). These CAR estimations are based on the assumption that sediment and OC accumulation are in a steady state during the period of accumulation/deposition. However, the "indirect way" or the chronosequential theory assumes that the temporal variations in soil properties in different aged sites fall into the same time trajectory of $\mathrm{OC}$ accumulation. This assumption requires a condition that these different sites had experienced similar driving factors of OC accumulation processes following tree growth after the restoration. While hydrological processes such as hydroperiod and tidal regime are considered to be one of the important drivers of OC accumulation, it is considered that these conditions do not largely vary among the sites and have been relatively stable over the time window in concern ( 30 years after restoration) given the same level of ground elevations which locate in the same 
forest (Fig. 2). Also, given the significant fraction of mangrove contribution to SOC (Fig. 7), the influence of C inputs from external systems may not be a significant factor in shaping the OC accumulation trajectories in the sites. Only the vegetation structures vary significantly among sites that may characterize the evolution of OC stock with forest age in our study site, Bakhawan Ecopark (Fig. 8). In addition, we consider that the AGB and BGB development in the sites follow a similar trajectory given the same level of soil salinity (Fig. 2) - one of the most important regulators of mangrove growth, and the same plantation spacing and species. Therefore, it is reasonable to consider that the OC accumulations in the different aged sites also follow the similar time trajectory, and thus Eq. (3) can be applied to estimate CAR in our study site.

\subsubsection{Carbon sink capacity}

Buried OC in the sediment strongly depends on many environmental conditions such as mangrove forest productivity, deforestation and degradation rate, sediment accretion, topography, tidal regime, and bioturbation activities (Alongi, 2014, Pérez et al., 2018). Significant exponential and/or linear increase of OC stock with early mangrove age (till YM) probably suggests that primary productivity might be key controlling factor for $\mathrm{C}$ accumulation (Fig. 8a). However, the correlation between the standing stock of sediment OC with ageing at the adult/matured stands are essentially not very significant, indicating that the size of the sediment OC pool at these two sites are not determined simply by the primary production of the vegetation but is also constrained significantly by some other biological or geophysical factors. Rates of OC accumulation defined by their respective slopes in the exponential curve (BS to MM) and linear curve (YM to MM) at individual site of $50 \mathrm{~cm}$ depth (5.9 - $33 \mathrm{~mol} \mathrm{~m}^{-2} \mathrm{yr}^{-1}$, and $15.93 \mathrm{~mol} \mathrm{~m}^{-2} \mathrm{yr}^{-1}$, respectively, Fig. $8 \mathrm{a}, \mathrm{b})$ are well within the ranges by chrono-sequential analysis of $1 \mathrm{~m}$ cores in restored $\left(12.7 \mathrm{~mol} \mathrm{~m}^{-2} \mathrm{yr}^{-1}\right.$, Lunstrum and Chen, 2014), intact (6 to $40 \mathrm{~mol} \mathrm{~m}^{-2} \mathrm{yr}^{-1}$, Marchand et al., 2017), or encroached mangroves (19 $\mathrm{mol} \mathrm{m}^{-2} \mathrm{yr}^{-1}$, Kelleway et al., 2016). System specific variabilities such as sedimentation rate, decomposition rate, rate of litterfall and root production may cause such differences in CAR among the reported mangroves. It is noted that OC\% in other mangrove soils were on average 2 times higher than the Bakhawan sites due to high terrestrial input to this forest driven by historical land use changes.

\subsection{Implication of blue carbon chrono-sequence}

There is a crucial need to improve scientific understanding on blue $\mathrm{C}$ dynamics and to develop an appropriate framework for blue $\mathrm{C}$ assessment and monitoring mechanisms for future policy development. Achieving improved scientific understanding on $\mathrm{C}$ sources, stocks and to monitor the changes in accumulation rate at the early development stage and adult stages would require practical tools and guidance to enable the conduct of proper $\mathrm{C}$ analyses. In this study, supply of OM from the mangrove vegetation, benthic algae and upstream sediment transport are recognized as controls of blue $\mathrm{C}$ at the mangrove sites and tidal flat. Impression of more mangrove-derived $\mathrm{C}$ input is evident with mangrove development. Such apportionment of OC sources at different mangrove stand ages should be useful to improve our future knowledge on origin of blue $\mathrm{C}$ in REDD+ accountings that is yet to register sedimentary OC within the reduced $\mathrm{C}$ emission scheme despite sediment being recognized as largest $\mathrm{C}$ pool in the mangrove ecosystem (Duarte et al., 2013). A prior knowledge on sources and character of OC (generally refractory or mangrove-derived and labile or algal-derived) would be beneficial for fostering mangrove plantation program. Greater mangrove-derived 
OC accumulation with ageing at the Bakhawan Ecopark might suggest long term storage of the refractory fraction, hence an effective return to REDD+ strategy. Another perspective is that any attempt of quantifying OC stock and accumulation rate following a plantation program should be well recorded in the relevant carbon accounting programs. For example, the Verified Carbon Standard Methodology (www.verra.org) existing for mangrove restoration projects that is certified under the Cleaner Development Mechanism (CDM) program of the United Nations Framework Convention on Climate Change (UNFCCC, 2011) assumes CAR for 0-20 years mangrove as $4 \mathrm{~mol} \mathrm{~m}^{-2} \mathrm{y}^{-1}$ after plantation (Lunstrum and Chen, 2014), which is 4 times lower than our chrono-sequence based estimate ( 16 mol m ${ }^{2} \mathrm{y}^{-1}$, linear slope for YM to MM stands). In IPCC 2013 supplementary (Tier 1, chapter 1), default $\mathrm{CO}_{2}$ emission factor from tidal flat was set to be 0 , while it was $-14 \mathrm{~mol} \mathrm{~m}^{-2} \mathrm{y}^{-1}$ (negative means accumulation) for the planted/rehabilitated mangroves, latter is in line with the older mangroves at Bakhawan Ecopark, but not with each developmental stage. Such assumption may lead to severely underestimated actual blue carbon sink capacity of the mangroves and consequently carbon emission value. Therefore, a differential yet steady trend of blue $\mathrm{C}$ potential based on short-term chrono-sequence can help define the utility of a mangrove restoration efforts.

\section{Conclusion}

This study is a first attempt to apply a chrono sequence (or space-for-time substitution) approach to evaluate the distribution and accumulation rate of carbon in a 30 year (max age) restored mangrove forest. From this study, it is clearly seen that mangrove tree development coincided with sediment OC concentration and accumulation, hence mangrove plantations are expected to accelerate OC sequestration at early plantation stage. Source apportionment of sedimentary OM suggests higher contribution of mangrove vegetation upland and riverine POM plus benthic algae down the tidal flat. The accumulation of $\mathrm{OC}$ in the sediment may be attributed to the increases in belowground root expansion with stand age. This chrono-sequence based estimates of OC stock and accumulation rate can be useful reference for setting up carbon accounting in the Rhizophora-dominated mangrove restoration projects.

\section{Acknowledgement}

We are grateful to the Japan International Cooperation Agency (JICA) and Japan Science and Technology Agency (JST) through the Science and Technology Research Partnership for Sustainable Development Program (SATREPS) for financially supporting the Project "Comprehensive Assessment and Conservation of Blue Carbon Ecosystems and their Services in the Coral Triangle (BlueCARES)". We thank Jesus Abad, John Michael Aguilar, Dominic Bautista, Bryan C. Hernandez and Mr. Tsuyoshi Kanda for their assistance during field surveys. We are grateful for the overall support given by the University of the Philippines, Diliman and Aklan State University to the project.

\section{Competing interests}

The authors declared no potential conflict of interests. 
https://doi.org/10.5194/bg-2021-359

Preprint. Discussion started: 19 January 2022

(c) Author(s) 2022. CC BY 4.0 License.

\section{References}

Alongi, D.M: Carbon cycling and storage in mangrove forests, Ann. Rev. Mar. Sci. 6, 195-219, doi: 10.1146/annurevmarine-010213-135020, 2014.

Alongi, D.M.: Global Significance of Mangrove Blue Carbon in Climate Change Mitigation, Sci., 2, 67, doi:10.3390/sci2030067 2020.

Alongi, D.M., Sasekumar, A., Chong, V.C., Pfitzner, J., Trott, L.A., Tirendi, F., Dixon, P., and Brunskill, G.J.: Sediment accumulation and organic material flux in a managed mangrove ecosystem: estimates of land-oceanatmosphere exchange in peninsular Malaysia, Mar. Geo., 208, 383-402, doi:10.1016/j.margeo.2004.04.016, 2004.

Ashton, E.C., Hogarth, P. J.. and Ormond, R.: Breakdown of mangrove leaf litter in a managed mangrove forest in Peninsular Malaysia, Hydrobiologia, 413: 77-88, 1999.

Arnaud, M., Morris, P.J., and Baird, A.J.: Fine root production in a chronosequence of mature reforested mangroves, New Phytologist, doi: 10.1111/nph.17480., 2021.

Andreetta, A., Fusi, M., Cameldi, I., Cimò, F., Carnicelli, S., and Cannicci, S.: Mangrove carbon sink, Do burrowing crabs contribute to sediment carbon storage? Evidence from a Kenyan mangrove system, J. Sea Res., 85: 524533, doi: 10.1016/j.seares.2013.08.010, 2014.

Bhomia, R.K., MacKenzie, R.A., Murdiyarso, D., Sasmito, S.D., and Purbopuspito, J.: Impacts of land use on Indian mangrove forest carbon stocks: implications for conservation and management, Ecol. Appl., 26, 1396e1408, doi: 10.1890/15-2143, 2016

Brown, R.D., Marotta, H., and Peixoto, R.B.: Hypersaline tidal flats as important "blue carbon" systems: a case study from three ecosystems, Biogeosciences. 18, 2527-2538. doi: 10.5194/bg-18-2527-2021, 2021.

Boto, K.G., and Wellington, J.T.: Soil characteristics and nutrient status in a Northern Australian mangrove forest, Estuaries, 7, 61-69, doi: 10.2307/1351957, 1984.

Bouillon, S., and H. T. S. Boschker.: Bacterial carbon sources in coastal sediments: a cross-system analysis based on stable isotope data of biomarkers, Biogeosciences, 3, 175-185, doi: 10.5194/bg-3-175-2006, 2006.

Cadaweng, E. A. and Aguirre, J. A.N.: Forest from the mud: the Kalibo experience. in: In Search of Excellence: Exemplary Forest Management in Asia and the Pacific, edited by: P.B. Durst, C. Brown, H.D. Tacio and M. Ishikawa, Bangkok, Thailand: FAO, 39-48, 2005.

Cameron, C., Hutley, L.B., Friess, D.A., et al.: Community structure dynamics and carbon stock change of rehabilitated mangrove forests in Sulawesi, Indonesia, Ecol. Appl., 29, e01810, doi: 10.1002/eap.1810, 2019. 
Chen, J., Wang, D., Li, Y., Yu, Z., Chen, S., Hou, X., White, J.R., and Chen, Z., :The carbon stock and sequestration rate in tidal flats from coastal China, Global Biogeochem. Cy., 34(11), p.e2020GB006772, doi: 10.1029/2020GB006772, 2020.

Donato, D.C, Kauffman, J.B., Murdiyarso, D., Kurnianto, S., Stidham, M., and Kanninen, M.: Mangroves among the most carbon-rich forests in the tropics, Nature Geosci., 4: 293-297, doi: 10.1038/ngeo1123, 2011.

Dung, L.V., Tue, N.T., Nhuan, M.T., and Omori, K.: Carbon storage in a restored Mangrove forest in Can Gio Mangrove Forest Park, Mekong Delta, Vietnam, Forest Ecol. Manag., 380, 31-40, doi: 10.1016/j.foreco.2016.08.032, 2016.

Duarte, C.M., Losada, I.J., Hendriks, I.E., Mazarrasa, I., and Marbà, N.: The role of coastal plant communities for climate change mitigation and adaptation, Nature Climate Change, 3(11): 961-968, doi: 10.1038/nclimate1970, 2013.

Duncan, C., Primavera, J.H., Pettorelli, N., Thompson, J.R., Loma, R.J.A., and Koldewey, H.J.: Rehabilitating mangrove ecosystem services: A case study on the relative benefits of abandoned pond reversion from Panay Island, Philippines, Mar. Pollut. Bull., 109(2): 772-782, doi: 10.1016/j.marpolbul.2016.05.049, 2016.

Gnanamoorthy, P., Selvam, V., Ramasubramanian, R., Chakraborty, S., Pramit, D., and Karipot, A.: Soil organic carbon stock in natural and restored mangrove forests in Pichavaram south-east coast of India, Indian J. Geo-Mar. Sci., 48, 2019, 801-808, 2019.

Gontharet, S., Mathieu, O., Lévêque, J., Milloux, M.J., Lesourd, S., Philippe, S., Caillaud, J., Gardel, A., Sarrazin, M., and Proisy, C.: Distribution and sources of bulk organic matter $(\mathrm{OM})$ on a tropical intertidal mud bank in French Guiana from elemental and isotopic proxies, Chemical Geology, 376: 1-10, doi: 10.1016/j.chemgeo.2014.03.009, 2014.

Goni, M.A., Moore, E., Kurtz, A., Portier, E., Alleau, Y., and Merrell, D.: Organic matter compositions and loadings in soils and sediments along the Fly River, Papua New Guinea, .Geochim. Cosmochim. Ac., 140: 275-296, doi: 10.1016/j.gca.2014.05.034, 2014.

Hatje, V., Masqué, P., Patire, V.F., Dórea, A., and Barros, F.: Blue carbon stocks, accumulation rates, and associated spatial variability in Brazilian mangroves, Limnol. Oceanogr., 9999: 1-14, doi: 10.1002/lno.11607, 2020.

Howard, J., Sutton-Grier, A., Herr, D., Kleypas, J., Landis, E., Mcleod, E., Pidgeon, E., and Simpson, S.: Clarifying the role of coastal and marine systems in climate mitigation, Front. Ecol. Environ., 15(1): 42-50, doi: 10.1002/fee.1451, 2017.

Jennarjahn, T.C.: Relevance and magnitude of 'Blue Carbon' storage in mangrove sediments: Carbon accumulation rates vs. stocks, sources vs. sinks, Estuar. Coast. Shelf S., 247, 107027, doi:10.1016/j.ecss.2020.107027, 2020. 

with multiple habitats, Sci. Total Environ., 724: 138205, doi: 10.1016/j.scitotenv.2020.138205, 2020.

Kauffman, J., Arifanti, V.B., Hernandez Trejo, H., del Carmen Jesús García, M., Norfolk, J., Cifuentes, M., Hadriyanto, D. and Murdiyarso, D.: The jumbo carbon footprint of a shrimp: carbon losses from mangrove deforestation, Front. Ecol. Environ., 15(4): 183-188, doi: /10.1002/fee.1482, 2017.

Kelleway, J.J., N. Saintilan, P.I. Macreadie, C.G. Skilbeck, A. Zawadzki, and P.J. Ralph.: Seventy years of continuous encroachment substantially increases 'blue carbon' capacity as mangroves replace intertidal salt marshes, Glob. Change Biol., 22 (3): 1097-1109, doi: 10.1111/gcb.13158, 2016.

Keil, R. G., and Mayer, L.M.: Mineral matrices and organic matter, in: Treatise on Geochemistry: Organic 600 Geochemistry 2nd Edition Volume 12, edited by: Falkowski, P.G., Freeman, K.H., Holland, H. and Turekian, K., Elsevier, Amsterdam, Netherlands, doi:10.1016/B978-0-08-095975-7.01024-X, 337-359, 2014.

Komada, T., Reimers, C.E., Luther III, G.W., and Burdige, D.J.: Factors affecting dissolved organic matter dynamics in mixed-redox to anoxic coastal sediments, Geochim. Cosmochim. Ac., 68(20): 4099-4111, 2004.

Kristensen, E.: Mangrove crabs as ecosystem engineers; with emphasis on sediment processes, J. Sea Res., 59, 3043, doi: 10.1016/j.seares.2007.05.004, 2008.

Kusumaningtyas, M.A., Hutahaeanc, A.A., Fischerd, H.W., Pérez-Mayod, M., Ransby, D., and Jennerjahn, T.C.: Variability in the organic carbon stocks, sources, and accumulation rates of Indonesian mangrove ecosystems, Estuar. Coast. Shelf S., 218, 310-323, doi: 10.1016/j.ecss.2018.12.007, 2019.

Lambs, L., Muller, E., and Fromard, F.: Mangrove trees growing in a very saline condition but not using seawater, Rapid Commun. Mass Spectrom., 22: 2835-2843, doi: 10.1007/s10021-010-9329-2, 2008.

Lovelock, C.E., Sorrell, B.K., Hancock, N., Hua, Q., and Swales, A.: Mangrove forest and soil development on a rapidly accreting shore in New Zealand, Ecosystems, 13(3): 437-451, doi: 10.1007/s10021-010-9329-2, 2010.

Lunstrum, A., and Chen, L.: Soil carbon stocks and accumulation in young mangrove forests, Soil Biol. Biochem., 75, 223-232, doi: 10.1016/j.soilbio.2014.04.008, 2014.

MacKenzie, R.A., Foulk, P.B., Klump, J.V., Weckerly, K., Purbospito, J., Murdiyarso, D., Donato, D.C. and Nam, V.N.: Sedimentation and belowground carbon accumulation rates in mangrove forests that differ in diversity and land use: a tale of two mangroves, Wetl. Ecol. Manag., 24(2): 245-261, doi: 10.1007/s11273-016-9481-3, 2016.

Marchand, C.,: Soil carbon stocks and burial rates along a mangrove forest chronosequence (French Guiana), Forest Ecol. Manag., 384: 92-99, doi: 10.1016/S0272-7714(02)00134-8, 2017. 

dynamic features of a mangrove-fringed coast in French Guiana, Estuar. Coast. Shelf S., 56: 119-130, doi: 10.1016/S0272-7714(02)00134-8, 2003.

Marchand, C., Albe'ric, P., Lallier-Verge`s, E., and Baltzer, F.: Distribution and characteristics of dissolved organic matter in mangrove sediment pore waters along the coastline of French Guiana, Biogeochemistry, 81:59-75, doi:10.1007/s10533-006-9030-x, 2006.

Matsumoto, K., Takanezawa, T., and Ooe, M.: Ocean tide models developed by assimilating TOPEX/POSEIDON Altimeter Data into hydrodynamical model: a global model and a regional model around Japan, J. Oceanogr., 56: 567-581, 200.

Matos, C.R., Berrêdo, J.F., Machado, W., Sanders, C.J., Metzger, E., and Cohen, M.C.: Carbon and nutrient accumulation in tropical mangrove creeks, Amazon region, Mar. Geo., 429: 106317, doi:10.1016/j.margeo.2020.106317, 2020.

Mayer, L.M.: Relationships between mineral surfaces and organic carbon concentrations in soils and sediments, Chem. Geol., 114: 347-363, doi:10.1002/lno.10478, 1994.

Miyajima, T., Hori, M., Hamaguchi, M., Shimabukuro, H., and Yoshida, G.: Geophysical constraints for organic carbon sequestration capacity of Zostera marina seagrass meadows and surrounding habitats, Limnol. Oceanogr., 62(3): 954-972, doi:10.1002/Ino.10478, 2017.

Miyajima, T., Y. Tsuboi, Y. Tanaka, and I. Koike.: Export of inorganic carbon from two Southeast Asian mangrove forests to adjacent estuaries as estimated by the stable isotope composition of dissolved inorganic carbon, $\mathrm{J}$. Geophys. Res., 114: G01024, doi:10.1029/2008JG000861, 2009.

Nellemann, C., Corcoran, E., Duarte, C.M., Valdés, L., De Young, C., Fonseca L, and Grimsditch, G.: Blue carbon: a rapid response assessment. United Nations Environment Programme, GRID-Arendal, 2009.

Nam, V.N., Sasmito, S.D., Murdiyarso, D., Purbopuspito, J., and MacKenzie, R.A.: Carbon stocks in artificially and naturally regenerated mangrove ecosystems in the Mekong Delta, Wetl. Ecol. Manag., 24:231-244, doi: 10.1007/s11273-015-9479-2, 2016.

Nilsson, C. and Wilson, S.D.: Convergence in plant community structure along a disparate gradient: are lakeshores inverted mountainsides?, The American Naturalist, 137: 774-790, doi: 10.1086/285193, 1991.

Nordhaus, I., Salewski, T., and Jennerjahn, T.C.: Interspecific variations in mangrove leaf litter decomposition arerelated to labile nitrogenous compounds, Estuar. Coast. Shelf. S., 192:137-148, doi:10.1016/j.ecss.2017.04.029, 2017. 

T., and Tabuchi, R.: Biomass and Production Rates of Fine Roots in Two Mangrove Stands in Southern Thailand, JARQ. 54(4): 349-360, doi:10.6090/jarq.54.349, 2020.

Parnell, A.C., Inger, R., Bearhop, S. and Jackson, A.L.: Source partitioning using stable isotopes: coping with too much variation, PloS one, 5(3): e9672, doi:10.1371/journal.pone.0009672, 2010.

Pe'rez, A., Libardoni, B.G., Sanders, C.J.: Factors influencing organic carbon accumulation in mangrove ecosystems, Biol. Letters, 14: 20180237, doi:10.1098/rsbl.2018.0237, 2018.

Pickett, S.T.A.: Space-for-time substitution as an alternative to long-term studies, in: Long-term studies in ecology, edited by: Likens G. E., Springer, 110-135, 1989.

Primavera, J.H., Sadaba, R.S., Lebata, M.J.H.L., and Altamirano, J.R.: Handbook of Mangroves in the Philippines Panay, SEAFDEC Aquaculture Department, Iloilo, Philippines, 106, 2004.

Salmo, S.G., Lovelock, C., and Duke, N.C.: Vegetation and soil characteristics as indicators of restoration trajectories in restored mangroves, Hydrobiologia, 720: 1-18, doi:10.1007/s10750-013-1617-3, 2013.

Prahl, F.G., Bennett, J.T., and Carpenter, R.: The early diagenesis of aliphatic hydrocarbons and organic matter in sedimentary particulates from Dabob Bay, Washington, Geochimic. Cosmochim. Ac., 44, 1967-1976, 1980.

Prasad, M.B.K., Kumar, A., Ramanathan, A.L., and Datta, D.K.: Sources and dynamics of sedimentary organic matter in Sundarban mangrove estuary from Indo-Gangetic delta, Ecological Processes, 6:8, doi:10.1186/s13717-0170076-6, 2017.

Pendleton, L., Donato, D.C., Murray, B.C., Crooks, S., Jenkins, W.A., Sifleet, S., Craft, C., Fourqurean, J.W., Kauffman, J.B., Marbà, N.. and Megonigal, P.: Estimating global "blue carbon" emissions from conversion and degradation of vegetated coastal ecosystems, PLoS One, 7(9): e43542, doi: 10.1371/journal.pone.0043542, 2012.

Ranjan, R.K., Routh, J., Ramanathan, A.L., and Klump, J.V.: Elemental and stable isotope records of organic matter input and its fate in the Pichavaram mangrove-estuarine sediments (Tamil Nadu, India, Mar. Chem., 126, 163172, doi: 10.1016/j.marchem.2011.05.005, 2011.

Ray, R., Michaud, E., Aller, R.C., Vantrepotte, V., Gleixner, G., Walcker, R., Devesa, J., Le Goff, M., Morvan, S. and Thouzeau, G.: The sources and distribution of carbon (DOC, POC, DIC) in a mangrove dominated estuary (French Guiana, South America), Biogeochemistry, 138(3), 297-321. doi:10.1007/ s10533-018-0447-9, 2018.

Ray, R., Thouzeau, G., Walcker, R., Vantrepotte, V., Morvan, S., Devesa, J., Le Goff, M., and Michaud, E.: Mangrove-derived organic and inorganic carbon export to the Atlantic Ocean? Time series study in the Guianese estuarine system, Latin America, J. Geophys. Res. Biogeo., 125: 8, e2020JG005739, doi: 10.1029/2020JG005739, 2020. 
Ren, H., Chen, H., Li, Z., and Han, W.: Biomass accumulation and carbon storage of four different aged Sonneratia apetala plantations in Southern China, Plant. Soil, 327: 279-291, doi: 10.1007/s11104-009-0053-7, 2010.

Shahraki, M., Fry, B., Krumme, U., and Rixen, T.: Microphytobenthos sustain fish food webs in intertidal arid habitats: a comparison between mangrove-lined and un-vegetated creeks in the Persian Gulf, Estuar. Coast. Shelf Sci., 149: 203-212, doi: 10.1016/j.ecss.2014.08.017, 2014.

Shen, H., Tu, Z., You, G., Shi, X.: Grain Size and Pollen of Sediments in Wanghu Lake (Central China) Linked to Hydro-Environmental Changes, Water, 12, 45; doi:10.3390/w12010045, 2020.

Sasmito, S.D., Kuzyakov, Y., and Lubis, A.A.: Organic carbon burial and sources in soils of coastal mudflat and mangrove ecosystems, Catena, 187: 104414, doi: 10.1016/j.catena.2019.104414, 2020.

Sanders, C.J., Smoak, J.M., Naidu, A.S., Sanders, L.M., and Patchineelam, S.R.: Organic carbon burial in a mangrove forest, margin and intertidal mud flat, Estuar. Coast. Shelf S., 90: 168-172, doi: 10.1016/j.ecss.2010.08.013, 2010.

Sharma, S., MacKenzie, R.A., Tieng, T., Soben, K., Tulyasuwan, N., Resanond, A., Blate, G. and Litton, C.M.: The impacts of degradation, deforestation and restoration on mangrove ecosystem carbon stocks across Cambodia, Sci. Total Environ., 706, 135416, doi: 10.1016/j.scitotenv.2019.135416. 2020.

Sheehan, L., Sherwood, E., Moyer, R.P., Radabaugh, K.R., and Simposon, S.: Blue carbon: an additional driver for restoring and preserving ecological services of coastal wetlands in Tampa Bay (Florida, USA), Wetlands, 39: 1317-1328, doi: 10.1007/s13157-019-01137-y, 2019.

Smith III, T. J., Boto, K. G., Frusher, S. D., and Giddins, R. L.: Keystone species and mangrove forest dynamics: the influence of burrowing by crabs on soil nutrient status and forest productivity, Estuar. Coast. Shelf. S., 33: 419432, doi:10.1016/0272-7714(91)90081-L, 1991.

Soper, F.M., MacKenzie, R.A., Sharma, S., Cole, T.G., Litton, C.M., and Sparks. J.P.: Non - native mangroves support carbon storage, sediment carbon burial, and accretion of coastal ecosystems, Glob. Change Biol., 25:4315-4326, doi: 10.1111/gcb.14813, 2019.

Van Hieu, P., Dung, L.V., Tai Tue, N., and Omori, K.: Will restored mangrove forests enhance sediment organic carbon and ecosystem carbon storage?, Regional Studies in Marine Science, 14: 43-52, doi: 10.1016/j.rsma.2017.05.003, doi: 10.1016/j.rsma.2017.05.003, 2017.

Valiela, I., Bowen, J. L. and York, J. K.: Mangrove forests: one of the world's threatened major tropical environments, Bioscience, 51:807-815, doi: 10.1641/0006-3568(2001)051[0807:MFOOTW]2.0.CO;2, 2001.

Wagai, R., Mayer, L.M., and Kitayama, K.: Extent and nature of organic coverage of soil mineral surfaces assessed 
https://doi.org/10.5194/bg-2021-359

Preprint. Discussion started: 19 January 2022

(c) Author(s) 2022. CC BY 4.0 License.

Wang, G., Yu, C., Singh, M., Guan, D., Xiong, Y., Zheng, R. and Xiao, R.: Community structure and ecosystem carbon stock dynamics along a chronosequence of mangrove plantations in China, Plant Soil, 464: 605-620, doi: 10.1007/s11104-021-04973-2, 2021.

Walker, L. R., Wardle, D. A., Bardgett, R. D., and Clarkson, B. D.: The use of chronosequences in studies of ecological succession and soil development, J. Ecol., 98, 725-736, doi:10.1111/j.1365-2745.2010.01664.x, 2010.

Walcker, R., Gandois, L., Proisy, C., Corenblit, D., Mougin, É., Ray, R., and Fromard, F.: Control of 'blue carbon' storage by mangrove ageing: evidence from a 66-year-chronosequence in French Guiana, Glob. Change Biol., 24: 2325-2338, doi: doi.org/10.1111/gcb.14100, 2018.

Xiong, Y., Liao, B., and Wang, F.: Mangrove vegetation enhances soil carbon storage primarily through in situ inputs rather than increasing allochthonous sediments, Mar. Pollut. Bull., 131: 378-385, doi:10.1016/j.marpolbul.2018.04.043, 2018.

Yoshikai, M., Nakamura, T., Suwa, R., Argamosa, R., Okamoto, T., Rollon, R., Basina, R., Primavera-Tirol, Y.H., Blanco, A.C., Adi, N.S. and Nadaoka, K.: Scaling relations and substrate conditions controlling the complexity of Rhizophora prop root system, Estuar. Coast Shelf S., 248:107014, doi:10.1016/j.ecss.2020.107014, 2021.

Zhang, Y., Xiao, L., Guan, D., Chen, Y., Motelica-Heino, M., Peng, Y. and Lee, S.Y.: The role of mangrove fine root production and decomposition on soil organic carbon component ratios, Ecol. Indic., 125: 107525, doi:10.1016/j.ecolind.2021.107525, 2021.

Figure legends

Figure 1: Map of the study area. BS (Bare sediment); PM (Pioneer mangrove, 3-month); YM (Young mangrove, 10-yr); AM (Adult mangrove, 20-yr); MM (Mature mangrove, 30-yr). The circle shows presence of long-tailed sandbar between AM and YM site. The north-west inland part and bank of the Aklan River are the dominant places for the naturally occurring mangroves.

Figure 2: Variation of physical and biogeochemical parameters in the sediments according to mangrove development.

Figure 3: Vertical profiles of sedimentary carbon properties during wet and dry season.

Figure 4: Vertical distribution of sediment surface area and OC loading during wet and dry season

Figure 5: Vertical profiles of porewater DOC during wet and dry season

Figure 6: Source identification of sedimentary organic matter using endmember carbon stable isotope ratio and OC:TN.

Figure 7: Source apportionment of sedimentary organic matter at different mangrove stages by applying bayesian mixing model with $\delta^{13} \mathrm{C}$ and OC:TN.

Figure 8: Slopes derived from linear and exponential relationship between (a) mangrove age and carbon stock (b) and carbon accumulation rate $(\mathrm{CAR})$. 
https://doi.org/10.5194/bg-2021-359

Preprint. Discussion started: 19 January 2022

(C) Author(s) 2022. CC BY 4.0 License.

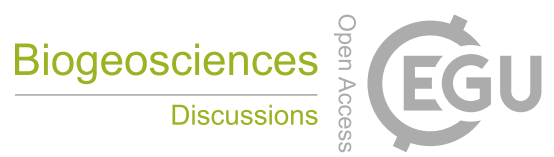

Table 1: The significance of effects of season, type and depth to TOC, DOC, bulk OC/TN ratio $\delta^{13} \mathrm{C}$ and $\delta^{15} \mathrm{~N}$ using ANOVA

on the basis of the generalized additive model (GAM). In the parameter of depth, the approximate significance of smooth term is shown.

\begin{tabular}{lllll}
\hline Parameters & Season & Type & Depth & \\
\hline TOC & 0.0855 & $<0.001$ & $<0.001$ & \\
DOC & 0.1986 & 0.003 & 0.127 & \\
OC:TN & $<0.001$ & $<0.001$ & 0.033 & 750 \\
$\delta^{13} \mathrm{C}$ & 0.0656 & $<0.001$ & 0.411 & \\
$\delta^{15} \mathrm{~N}$ & 0.0148 & 0.0061 & 0.737 & \\
\hline
\end{tabular}


https://doi.org/10.5194/bg-2021-359

Preprint. Discussion started: 19 January 2022

(c) Author(s) 2022. CC BY 4.0 License.

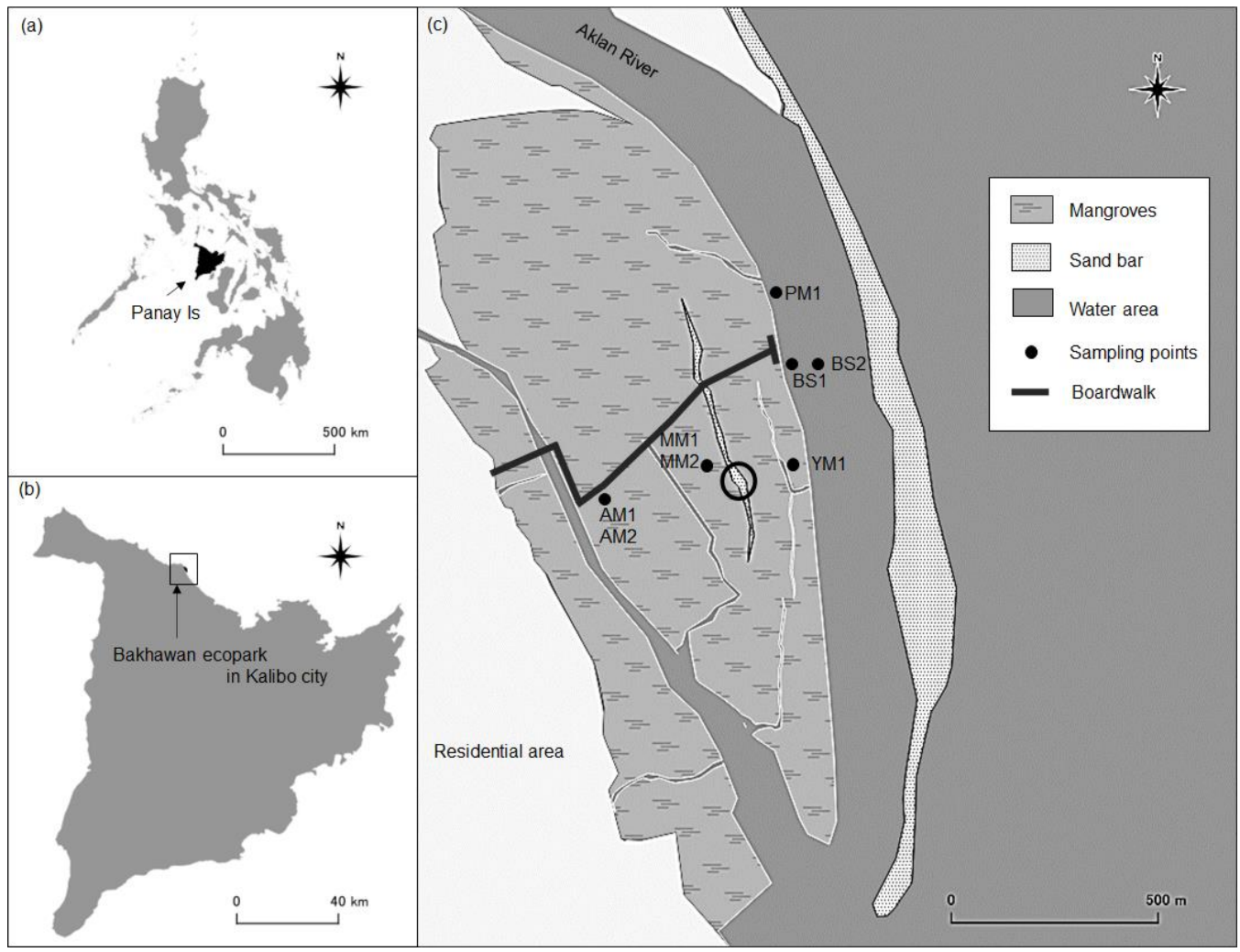

Fig. 1. 

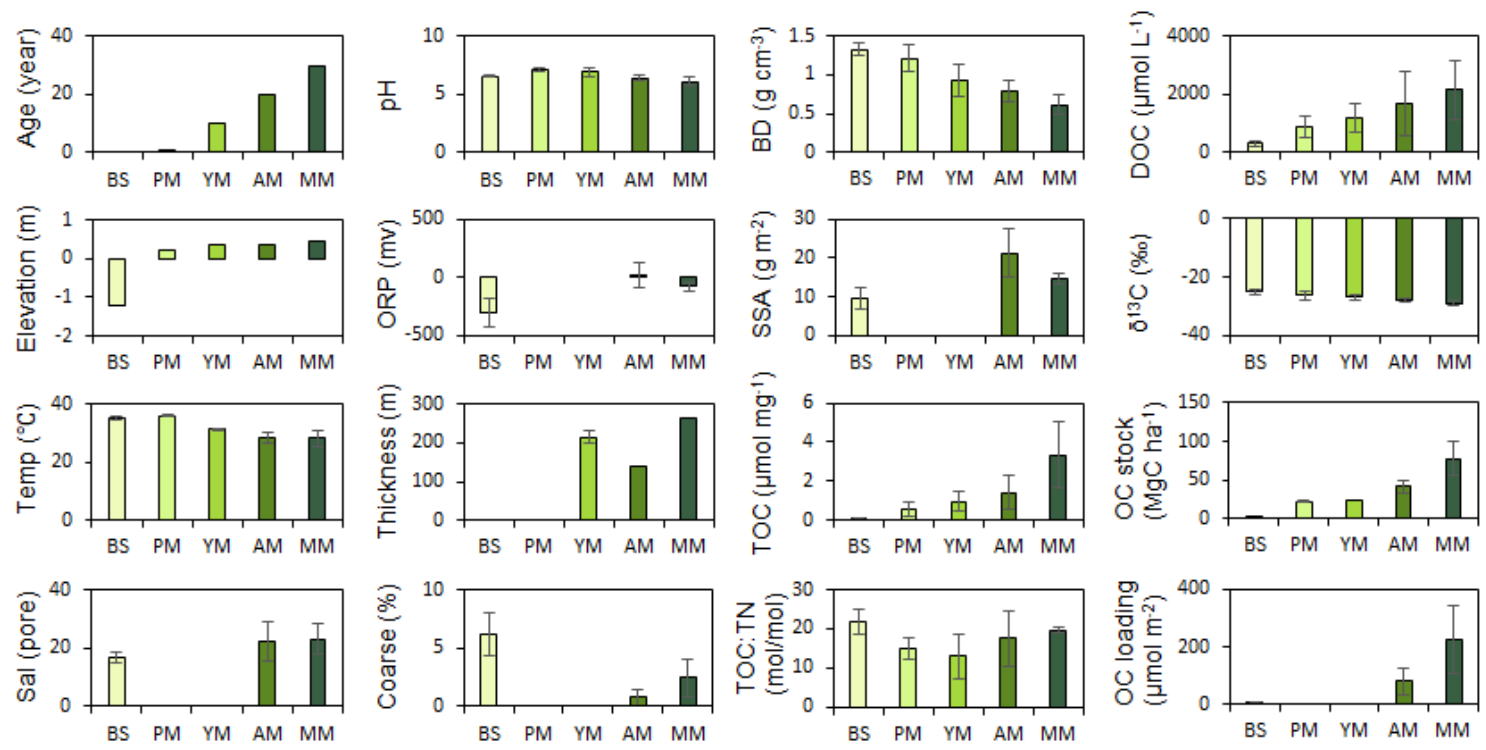

Fig. 2. 
https://doi.org/10.5194/bg-2021-359

Preprint. Discussion started: 19 January 2022

(c) Author(s) 2022. CC BY 4.0 License.

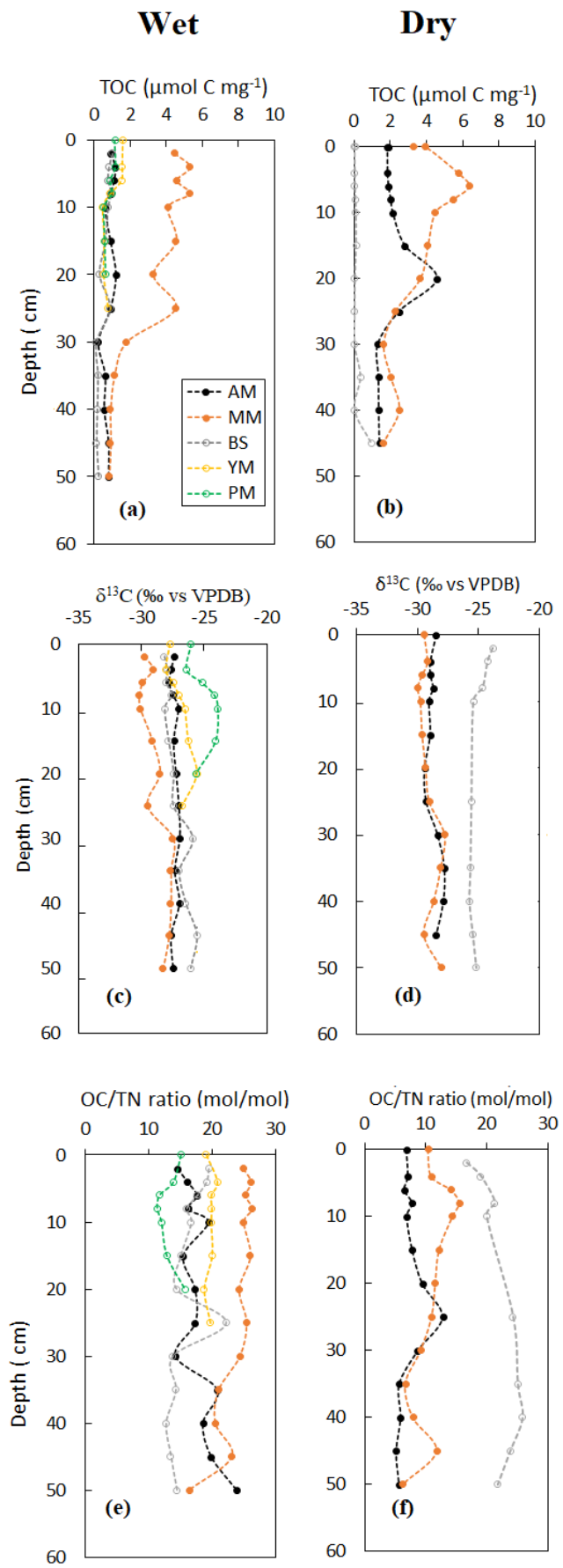

Fig. 3. 
https://doi.org/10.5194/bg-2021-359

Preprint. Discussion started: 19 January 2022

(c) Author(s) 2022. CC BY 4.0 License.

Wet
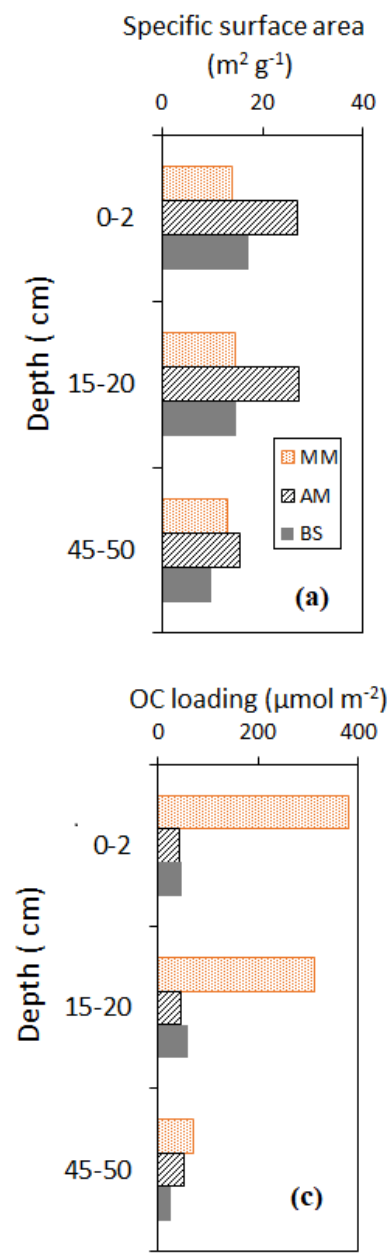

Dry

Specific surface area

$$
\left(\mathrm{m}^{2} \mathrm{~g}^{-1}\right)
$$

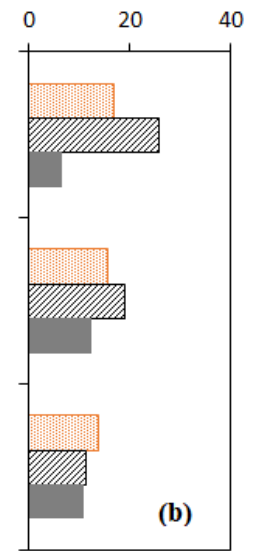

OC loading ( $\mu \mathrm{mol} \mathrm{m} \mathrm{m}^{-2}$ )

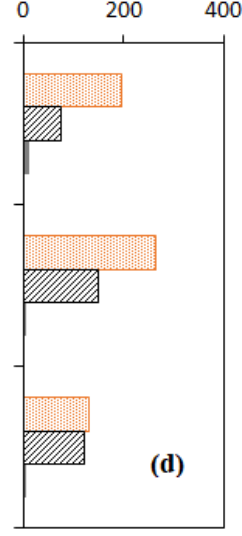

Fig. 4. 
https://doi.org/10.5194/bg-2021-359

Preprint. Discussion started: 19 January 2022

(C) Author(s) 2022. CC BY 4.0 License.

800

Wet

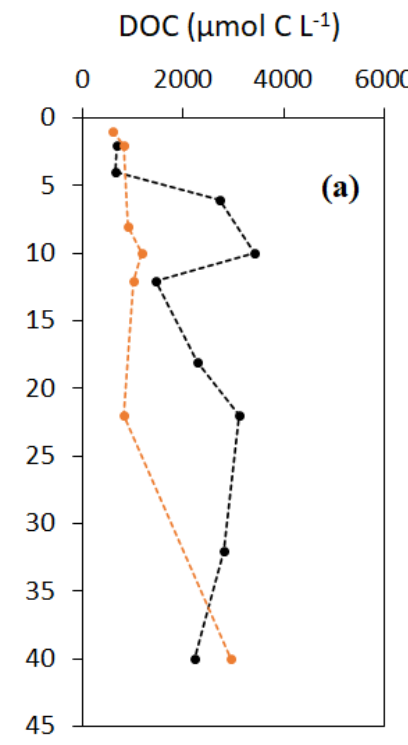

Dry

DOC $(\mu \mathrm{mol} \mathrm{C} \mathrm{L-1)}$

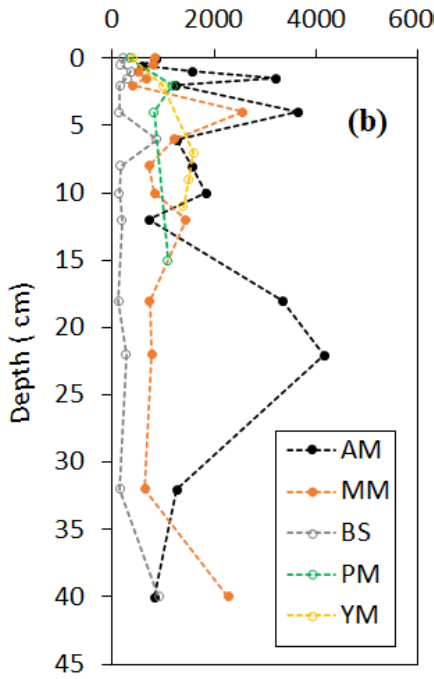

Fig. 5. 
https://doi.org/10.5194/bg-2021-359

Preprint. Discussion started: 19 January 2022

(C) Author(s) 2022. CC BY 4.0 License.
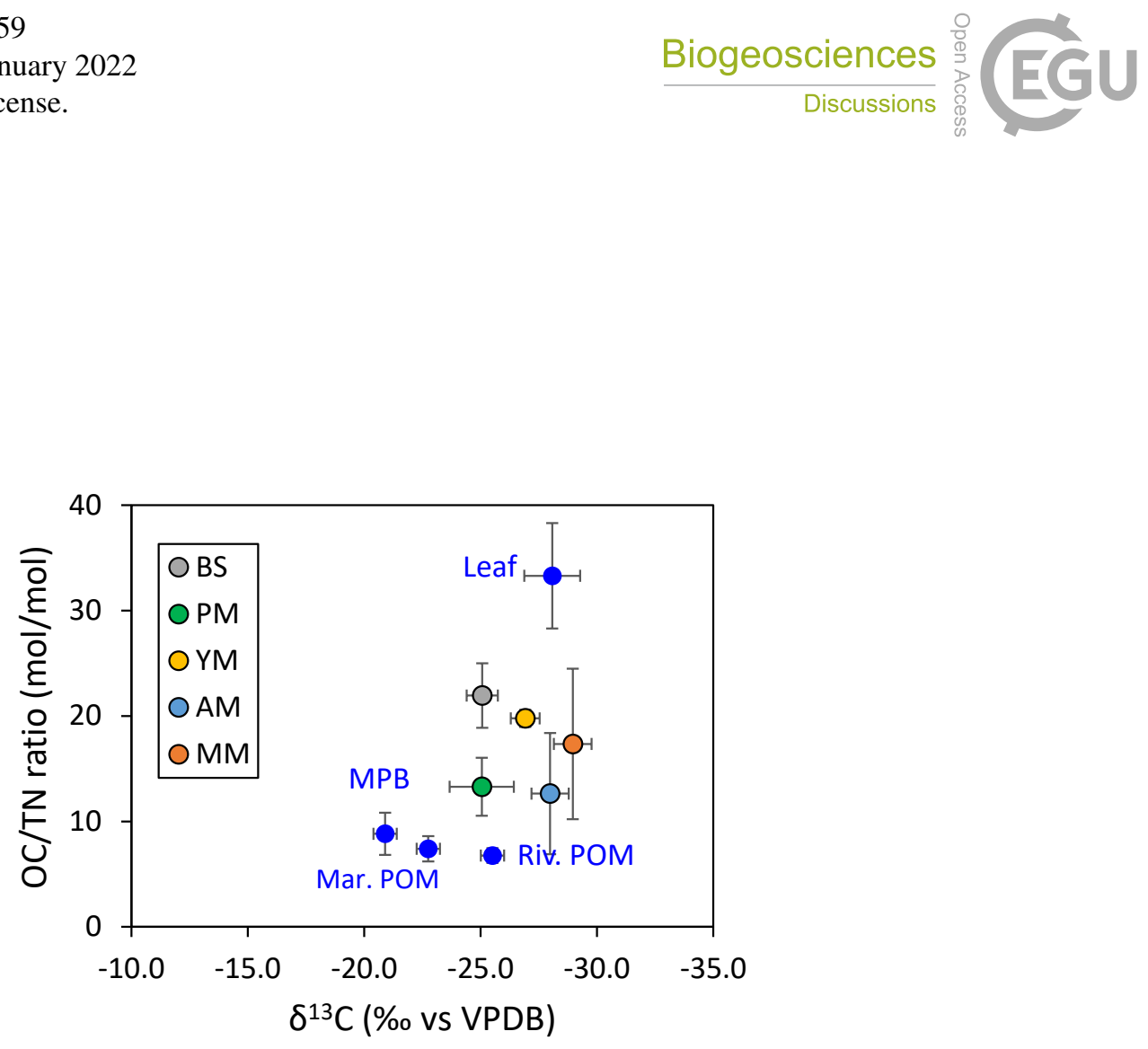

Fig. 6.

810 
https://doi.org/10.5194/bg-2021-359

Preprint. Discussion started: 19 January 2022

(c) Author(s) 2022. CC BY 4.0 License.

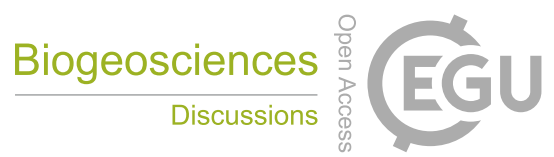

(c) $\underset{\mathrm{BY}}{(1)}$
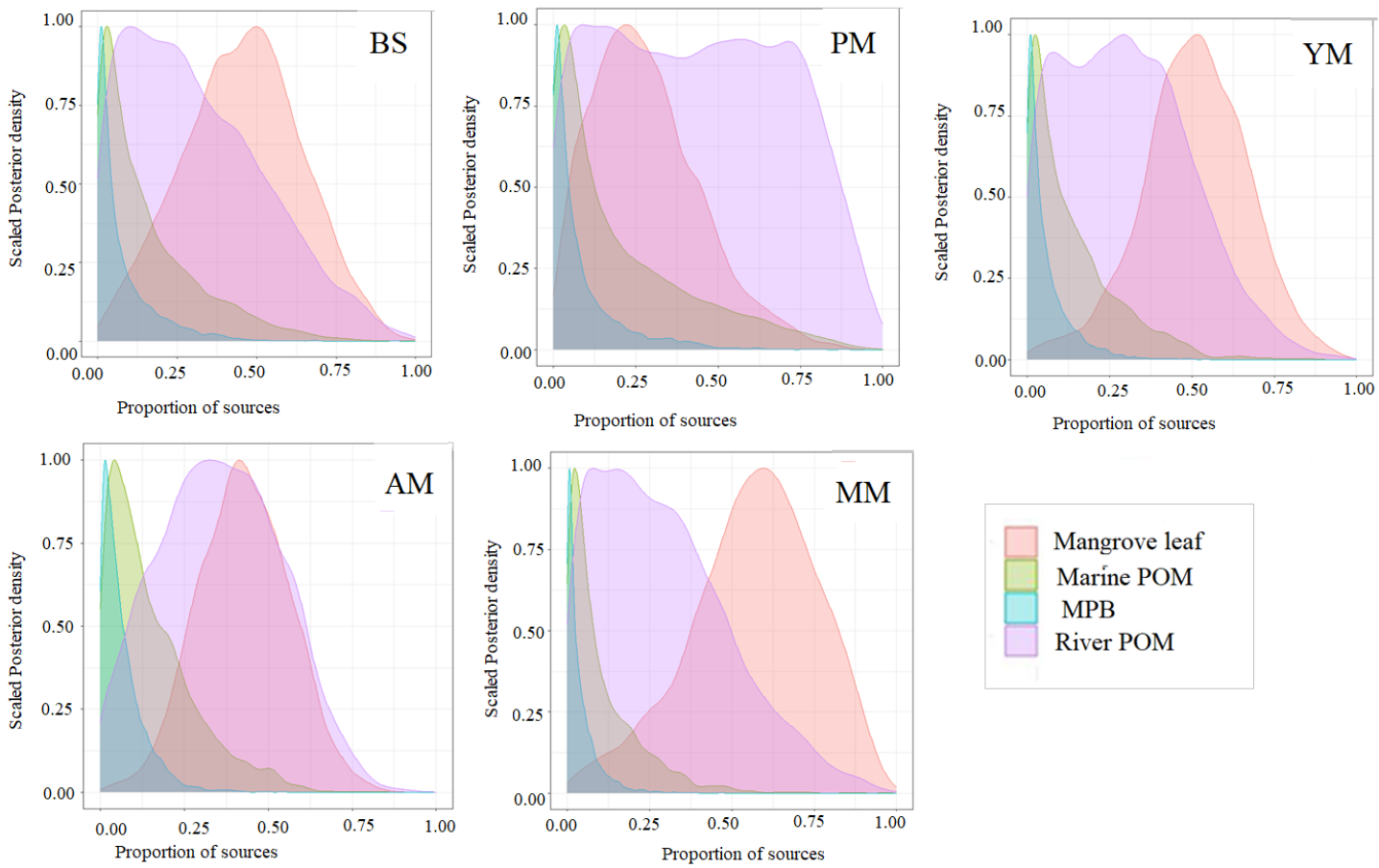

Mangrove leaf

Marine POM

MPB

River POM

Fig. 7. 
https://doi.org/10.5194/bg-2021-359

Preprint. Discussion started: 19 January 2022

(C) Author(s) 2022. CC BY 4.0 License.
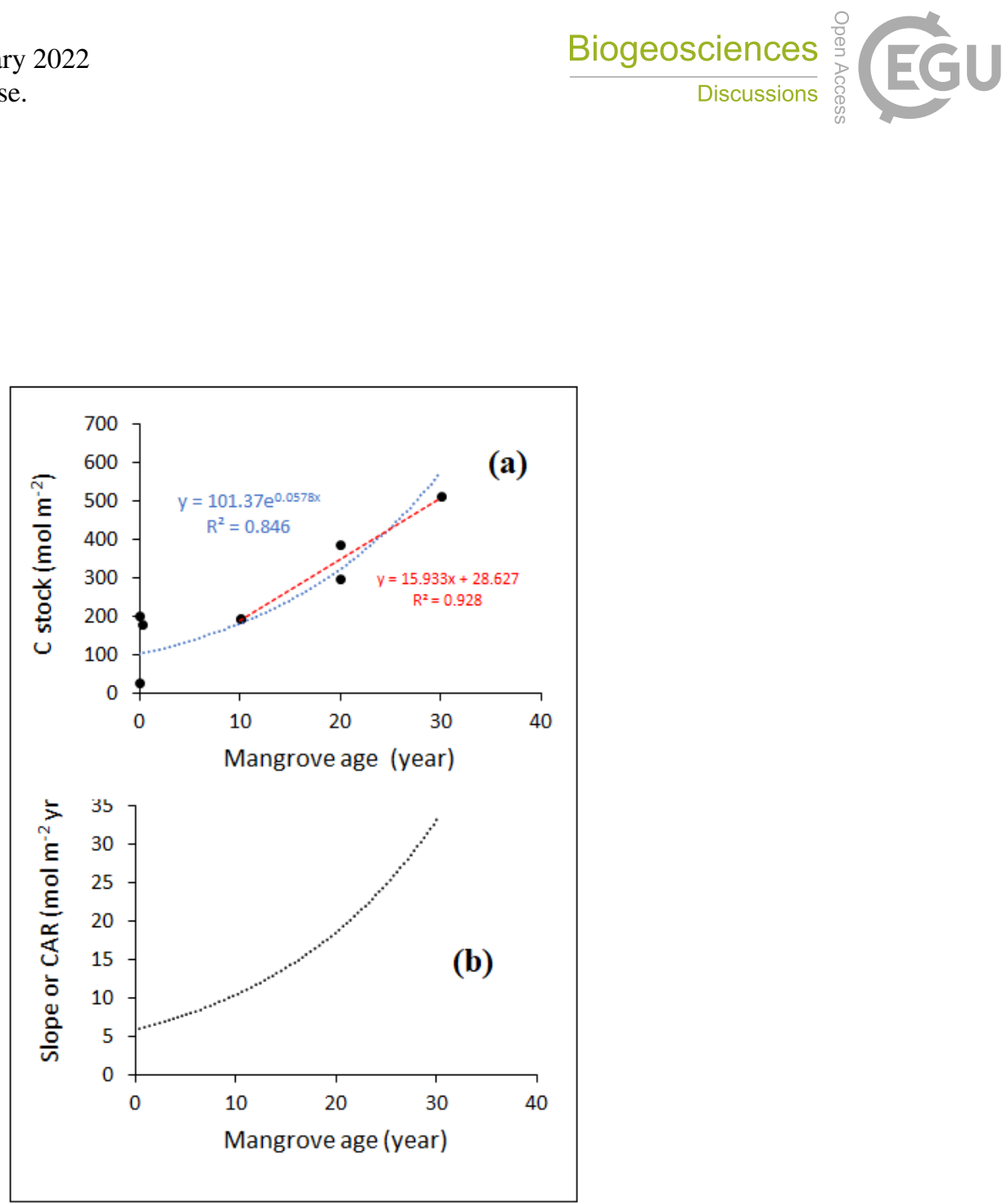

Fig. 8. 